DE89 011019

Hydrologic Modeling to

Predict Performance of

Shallow Land Burial Cover Designs

at the Los Alamos National Laboratory

John W. Nyhan 


\section{DISCLAIMER}

This report was prepared as an account of work sponsored by an agency of the United States Government. Neither the United States Government nor any agency Thereof, nor any of their employees, makes any warranty, express or implied, or assumes any legal liability or responsibility for the accuracy, completeness, or usefulness of any information, apparatus, product, or process disclosed, or represents that its use would not infringe privately owned rights. Reference herein to any specific commercial product, process, or service by trade name, trademark, manufacturer, or otherwise does not necessarily constitute or imply its endorsement, recommendation, or favoring by the United States Government or any agency thereof. The views and opinions of authors expressed herein do not necessarily state or reflect those of the United States Government or any agency thereof. 


\section{DISCLAIMER}

Portions of this document may be illegible in electronic image products. Images are produced from the best available original document. 



\section{CONTENTS}

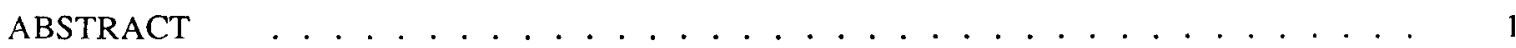

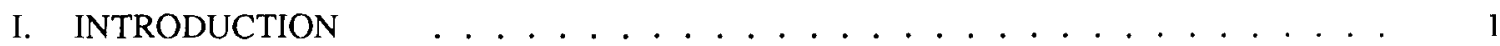

A. Burial Site Closure Performance Requirements . . . . . . . . . . . . . . . 2

B. Role of Water Balance Models in Landfill Evaluations _. . . . . . . . . . . . 3

C. Scope and Limitations of the Study . . . . . . . . . . . . . . . . . . . 4

II. CALIBRATION OF A HYDROLOGIC MODEL WITH FIELD DATA $\ldots \ldots$

A. Field Experiment . . . . . . . . . . . . . . . . . 5

B. Model Calibration Efforts . . . . . . . . . . . . . . . . 7

1. Saturated Hydraulic Conductivity . . . . . . . . . . . . . . . . 9

2. Bare Soil Evaporation Parameter _. . . . . . . . . . . . . . . . . 9

3. Leaf Area Index . . . . . . . . . . . . . . . . . . . . 10

C. Simulation Results f. . . . . . . . . . . . . . . . 11

III. PROTOCOL FOR EXTRAPOLATING CREAMS CLIMATIC FACTORS TO OTHER WASTE SITES AT LOS ALAMOS $\ldots \ldots \ldots \ldots \ldots$

IV. USE OF CREAMS TO DESIGN CLOSURE COVERS FOR LOS ALAMOS LANDFILLS 15

A. Effects of Vegetative Cover and Trench Cap Thickness . . . . . . . . . . . . . 17

B. Precipitation Received at the Site . . . . . . . . . . . . . 28

C. Effect of Runoff Curve Number _. . . . . . . . . . . . . . . . 28

V. USEFULNESS OF SIMULATIONS FOR WASTE MANAGEMENT PRACTICES AT LOS ALAMOS AND RECOMMENDATIONS FOR FUTURE STUDIES . . . . . . 29

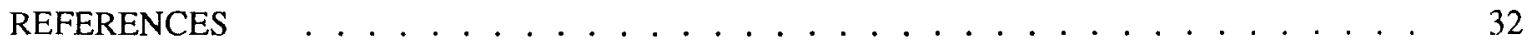




\title{
HYDROLOGIC MODELING TO PREDICT PERFORMANCE OF SHALLOW LAND BURIAL COVER DESIGNS AT THE LOS ALAMOS NATIONAL LABORATORY
}

\author{
by
}

\author{
John W. Nyhan
}

\begin{abstract}
The water balance relationships of two shallow land burial (SLB) cover configurations were studied using a hydrologic model in a preliminary attempt to design waste disposal site covers for successful long-term closure at Los Alamos. Burial site performance requirements for site closure are first discussed, along with the role of hydrologic models in assessing the dynamics of the hydrology of the SLB cover. The calibration of a hydrologic model using field data from two SLB cover designs is then described, followed by an analysis of long-term climatic model input parameters across Los Alamos National Laboratory. These two calibrated models are then used to cvaluate the influence of vegetation, precipitation, and runoff curve number on the design of SLB covers within Los Alamos county. Future directions of field research efforts and subscquent hydrologic modeling activities were recommended in terms of their uscfulness for waste management decisions to be made at Los Alamos.
\end{abstract}

\section{INTRODUCTION}

Although shallow land burial (SLB) of wastes began with early civilizations, recently developed rules and regulations require the ability to model hydrologic processes on SLB systems used for the disposal of wastes. An important part of hydrologic models for SLB systems is the surface water balance. This balance is an accounting or budgeting of water from the soil through its entire profile to the plant rooting depth-an accounting that includes input, output, and storage terms. Precipitation is the input to the system, whereas outputs are net surface runoff, evaporation and transpiration losses, and net subsurface flow out of the plant rooting zone. The subsurface flow can be either lateral or vertical; the vertical downward flow below the root zone is often called decp seepage or percolation. Changes in soil water content account for gains or losses of water stored in the soil profile (see Fig. 1).

Trench covers that isolate wastes at SLB facilities are subject to the interactive factors of a dynamic hydrologic system. Failure of the trench cap can be caused by failure of enginecred barriers, excessive soil erosion, plant and animal intrusion into the waste, and percolation of water into the waste, ultimately leading to mobilization and transport of wastes. The importance of water management at SLB facilitics in reducing and/or eliminating these failures were summarized by Nyhan (1989).

Infiltration and percolation of water through the soil and out of the plant rooting depth define the upper boundary and initial conditions for subsurface water flow and radionuclide transport calculations. However, because water management in the trench cover can vary the potential subsurface water flux by orders of magnitude, SLB designs should include a thorough analysis of surface and near-surfacc water dynamics to calculate a water balance and the upper boundary conditions for subscquent subsurface flow calculations. Thus, water balance relationships must be taken into account if SLB sites are to be hydrologically characterized and successfully closed out. 


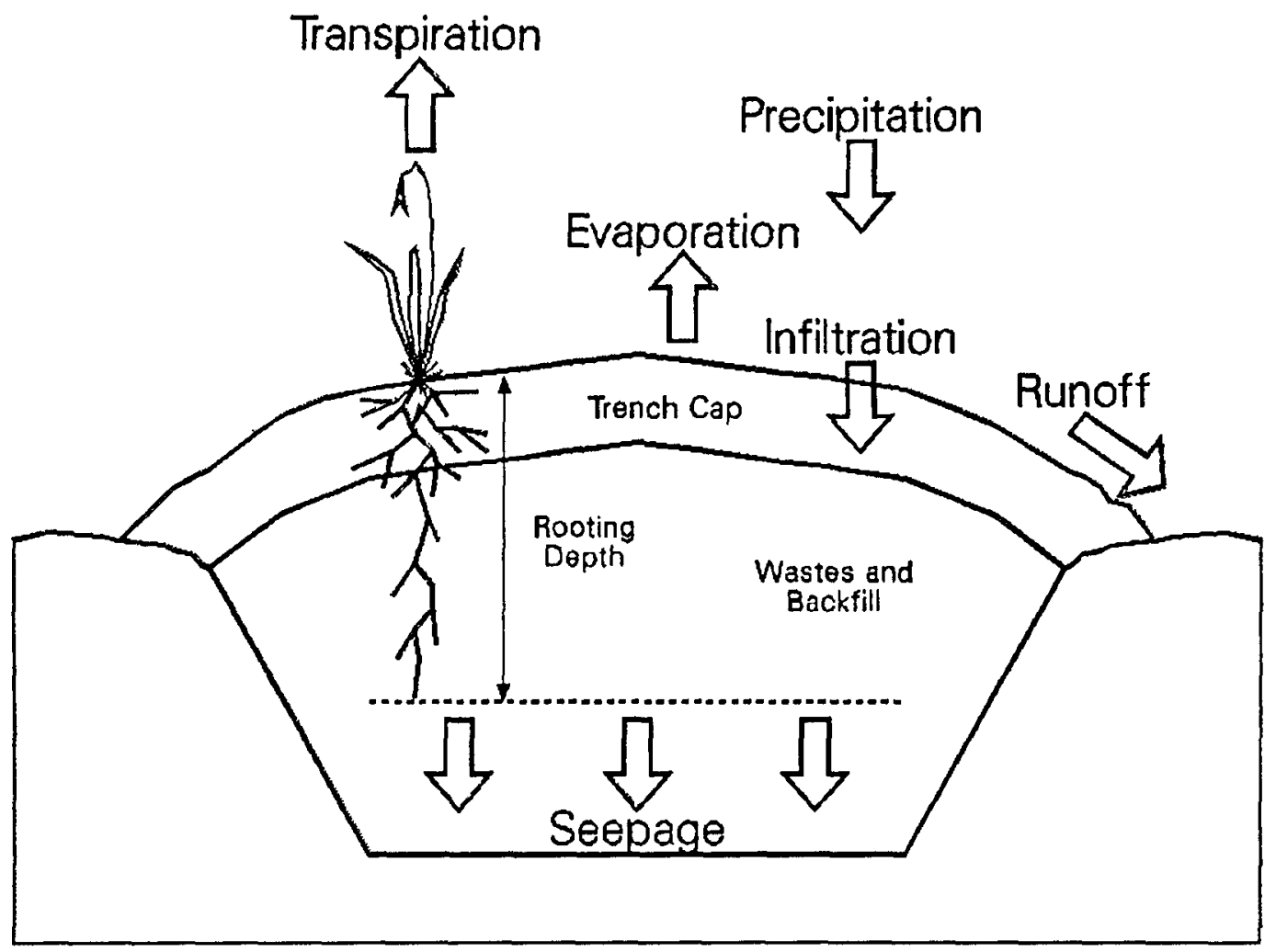

Fig. 1. Hydrologic processes affecting SLB sites.

\section{A. Burial Site Closure Performance Requirements}

Federal and State site closure performance requirements must be met in order to close a landfill site. Performance requirements may be written in the form of prescriptive requirements or performance objectives. The prescriptive requirement demands specific technical design features. Performance objectives mandate a level of performance without stipulating how that performance should be attaincd. Use of performance objectives significant technical substantiation by site operators to show that closure designs will mect intended performance objectives. Performance objectives allow actions to be tailored to sitc-specific conditions, but do not preclude adoption of prescriptive requirements.

Because DOE Order 5820.2 contains only general requirements for site closure, other regulations, which are pertinent but perhaps not legally applicable, should be reviewed in the development of sitespecific performance requirements. Specific performance requirements found in present regulations 10 CFR 61 (US NRC 1982), 40 CFR 265 (US EPA 1980), and 50 CFR 191 (US EPA 1985) for closure of disposal sites containing low-level wastes (LLW), transuranic (TRU) wastes, or hazardous wastes are shown in Table I. Regulations for disposal of LLW and TRU are based both on sitc selection and design rcquirements stipulated under these requirements and on a site containing only one waste type.

It is the intent of the post-closure requirements (Table I) to limit the exposure of the general public to radioactive and hazardous wastes for time periods ranging from 100 to 10,000 years. However, the hydrologic model used in the current study was developed using the results of about only 40 ycars of field research. Clearly, we must extrapolate model results over time periods for which there are no supporting data. 
TABLE I. Postclosure Requirements for Disposal of LLW, TRU, and Hazardous Waste (US NRC 1982; US EPA 1980; US EPA 1985)

\begin{tabular}{|c|c|c|}
\hline Statute & Sites Governed & Postclosure Performance Objectives \\
\hline $\begin{array}{l}\text { Doe Order } \\
5820.2 \\
\text { Chapter III }^{a}\end{array}$ & DOE low-level waste disposal sites. & $\begin{array}{l}\text { - Annual dose limit of } 500 \text { mrem to any member } \\
\text { of the general public; doses must be maintained } \\
\text { at levels as low as reasonably achievable. (Oper- } \\
\text { ational limit only. No DOE-wide limits exist for } \\
\text { closure.) }\end{array}$ \\
\hline $10 \mathrm{CFR} 61^{b}$ & $\begin{array}{l}\text { Commerical sites for shallow-land } \\
\text { disposal of low-level waste. }\end{array}$ & $\begin{array}{l}\text { - Annual dose to any member of the general public } \\
\text { not to exceed } 25 \mathrm{mrem} \text { to whole body, } 75 \mathrm{mrem} \\
\text { to thyroid, } 25 \mathrm{mrem} \text { to any other organ. } \\
\text { - Protection of individuals from inadvertent intru- } \\
\text { sion. } \\
\text { - Long-term stability of site ( } 500 \mathrm{yr} \text { ). } \\
\text { - } 100 \text {-yr maximum institutional control period. } \\
\text { - Buffer zone. }\end{array}$ \\
\hline 40 CFR $191^{c}$ & $\begin{array}{l}\text { Sites developed for management } \\
\text { and disposal of spent nuclear fuel, } \\
\text { high-level and transuranic radioac- } \\
\text { tive wastes. }\end{array}$ & $\begin{array}{l}\text { - Long-term stability of site }(10,000 \mathrm{yr}) \text {. } \\
\text { - Meet release limits for specific radionuclides } \\
\text { (191.13). } \\
\text { - Annual dose to any member of the general public } \\
\text { not to exceed } 25 \text { mrems to whole body, } 75 \text { mrem to } \\
\text { thyroid, } 25 \text { mrems to any other organ, for } 1000 \text { yrs } \\
\text { after (undisturbed) disposal. } \\
\text { - Meet specific ground water protection requirc- } \\
\text { ments for } 1000 \text { yr disposal (undisturbed). }\end{array}$ \\
\hline 40 CFR $265^{d}$ & Hazardous waste facilities. & $\begin{array}{l}\text { - Minimize need for further maintenance of haz- } \\
\text { ardous waste constituents, leachate, contaiminated } \\
\text { rainfall, or waste composition products to the } \\
\text { ground or surface waters or the atmosphere. }\end{array}$ \\
\hline
\end{tabular}

${ }^{a}$ Radioactive waste management, management of low-lcvel waste, currently replaced by DOE Order 5820.2A.

${ }^{b}$ Licensing requirements for land disposal of radioactive waste.

${ }^{c}$ Environmental standards for the management and disposal of spent nuclear fuel and high-level and transuranic radioactive wastes.

${ }^{d}$ Interim status standards for owners and operators of hazardous waste treatment, storage, and disposal facilities.

\section{B. Role of Water Balance Models in Landfill Evaluations}

Water balance at an SLB facility, as conceptualized in Fig. 1, reflects the surface and near-surface water balance dynamics, that control the performance of SLB facilities. If we restrict our attention to net rates and amounts and consider one-dimensional movement of water in the soil profile, then we have the following simplified water balance equation: 


$$
\frac{\mathrm{d} s}{\mathrm{dt}}=\mathrm{P}-\mathrm{Q}-\mathrm{ET}-\mathrm{L},
$$

where

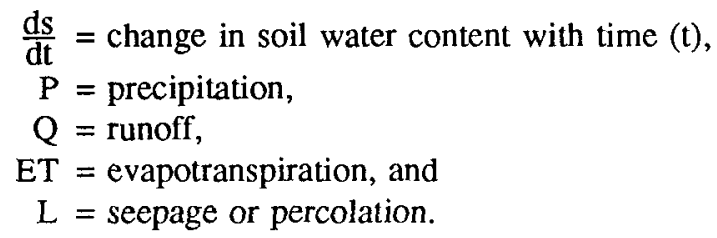

Applying this equation to the plant rooting depth within the closure cover at an SLB sitc illustrates that the rate of change in soil moisture with time (ds/dt) is equal to the difference between input $(\mathrm{P})$ and output (Q, ET, and L).

The CREAMS model (a field scale model for chemicals, runoff, and erosion from Agricultural Managcment Systems) was initially developed and intended for modeling field-scale agricultural systcms (Kniscl 1980) using the water balance approach. The model has since been used in several areas of waste management research in semiarid climates, including erosion studies (Nyhan and Lane 1982), water balance and primary production of desert shrubs (Lane et al. 1984), and landfill cover design (Hakonson et al. 1982, Nyhan et al. 1984). CREAMS has been tested in a limited way with respect to percolation of water below the plant rooting zone in agricultural monocultures, but not in any detail with respect to the effects of native plant cover on soil water storage, such as in the field studies at Waste Disposal Area B (Nyhan and Barnes 1989). A very detailed user's manual (Lane 1984) was written on the use of CREAMS to perform water balance calculations.

In the present study, CREAMS was used in the daily rainfall/runoff mode to obtain a complete water budget (estimates of runoff, evapotranspiration, percolation and soil-water storage, or water content of the soil column to the depth of the rooting zone) on each day that there was a precipitation cvent using the water balance equation. Monthly and annual water budgets were also obtained. The model is one-dimensional, calculating the process of vertical transport of water in the soil column using a seven layer representation of the profile from the surface extending through the rooting zone of the vegetative cover. Initial responses to precipitation are calcualted on a daily time-step using a modification of the Soil Conservation Service (SCS) curve number model (Knisel 1980).

\section{Scope and Limitations of the Study}

This report deals only with the hydrologic component of the CREAMS model and should probably only be applied to a consideration of relatively flat (dominant downhill slopes less than 7\%) portions of waste disposal areas, because this is the extent of our current knowledge. The erosion component of CREAMS is actually driven by the hydrologic component of CREAMS, and could be used to evaluate sites for soil erosion losses with time in the future. However, we limited our attention to the daily rainfallrunoff model discussed earlier and applied it only to a configuration we had field and modeling experience (unlike the steep sideslopes found on and adjacent to some of the SLB sites at Los Alamos).

The scope of the study also did not involve randomly varying the soil, plant, topographic, and climatic input parameters or evaluating CREAMS daily rainfall/runoff results for each combination of parameters. CREAMS contains six main soil parameters, two derived soil parameters, three major descriptors of the plant parameters, three major topographic parameters, and three major categories of climatic data. Performing random CREAMS simulations for this number of variables would take much more time than was allocated in this program and would result in many simulation results that would be hydrologically and realistically meaningless for some combinations of parameters.

The CREAMS model is a widely known and accepted model that is increasingly used in waste management. However, research scientists, users, and program administrators should not see the CREAMS model as an absolutely accurate and final representation of hydrologic processes in the surface and ncarsurface areas of SLB facilities. Consequently, the CREAMS model is one step in continuing efforts to understand and improve models of the water balance and associated technology for surface water management at landfill sites. 
The steps we took to calibrate the CREAMS model for several SLB cover designs are first described in the next section of this report. An evaluation of the precipitation and air temperature model input terms to $b c$ used in the subsequent modeling efforts is then described, comparing long-term climatic data collected across the Los Alamos National Laboratory. CREAMS models calibrated for two SLB cover designs are then used to evaluate the influence of vegetation, precipitation, and runoff curve number on the design of SLB covers within the Laboratory. In the last section, future field research and hydrologic modeling activities are recommended for improving the technology for future waste management decisions to be made for landfills in Los Alamos.

\section{CALIBRATION OF A HYDROLOGIC MODEL WITH FIELD DATA}

In order to build confidence and credibility in the predictions of a hydrologic model, the model must be calibrated against hydrologic data collected in the ficld. In the succeeding subsections, a ficld experiment is first described in which total water balance relationships of two SLB trench cap designs were measured in the field for three years. Calibration of the CREAMS model with these field data is then described.

\section{A. Field Experiment}

The purpose of the Integrated Test Plot (ITP) cover demonstration was to monitor and compare watcr balance on the conventional trench cap design (referred to in this report as Control Plots 1 and 2), similar to that used in Los Alamos for low-level radioactive waste disposal (Fig. 2), with that on an improved design (referred to in this report as Improved Plots 1 and 2; see Fig. 3). The demonstration plots (2 plots/cover design) were instrumented and designed so that a complete water balance of precipitation falling on the plots at the Los Alamos Experimental Enginecred Test Facility (EETF; Depoorter 1981) could be made (Nyhan et al. 1989b). The plots, which were about 3 by $10 \mathrm{~m}$, were constructed and instrumented (Figs. 2 and 3) to provide measures of runoff, soil water storage, and seepage, as measured by leachatc production from the trench drains emplaced in the plots. Except for a small amount of water sprinkled on the plots in mid-1984, to aid in establishing vegetation, only natural precipitation was added to the plots during the course of the study.

The technology for soil erosion control on both cover designs consisted of applying a 60 to $70 \%$ cover of gravel (about 2-cm diameter) and a plant cover of blue grama grass (Bouteloua gracilis) and western wheatgrass (Agropyron smithii). A dominant downhill slope of only $0.5 \%$ was used in the improved design, which successfully insured that no runoff was generated over the course of the experiment (in an attempt to simplify the estimation of the other parameters in the water balance equation an to test the performance limits of the two cover designs in preventing deep percolation).

The conventional and improved cover designs vary significantly beneath the soil surface. The conventional trench cap design consisted of $15 \mathrm{~cm}$ of topsoil emplaced on top of $76 \mathrm{~cm}$ of crushed tuff backfill. Cesium iodide tracer was applied to the tuff backfill at the interface between the bottom of the cover and the underly tuff backfill. Notice that this tracer layer conceptually separated the laycrs designated in this report as the trench cap (above the cesium iodide tracer layer) and beneath the trench cap (below the tracer layer). The crushed tuff backfill beneath the cesium iodide layer would normally contain low-level radioactive wastes in an actual waste disposal sitc in Los Alamos.

The improved cover plot design contains provisions for potential subsurface water management and for controlling biological intrusion by plant roots and animals (Fig. 3). Approximately $71 \mathrm{~cm}$ of topsoil was cmplaced on top of $46 \mathrm{~cm}$ of pea gravel and gravel (5- to 10-mm diameter) to provide for soil water storage and to form a capillary barrier to divent the vertical flow of water resulting from precipitation infiltrating the trench cap. The integrity of the soil/gravel interface was maintained with a very high conductivity geotextile (600x brand, manufactured by MIRAFI, Inc., El Toro, CA 92630). A 5\% lateral slope (across the width of the plot) on this interface and a large difference in the saturated hydraulic conductivities of these two layers should theoretically cause the downward flow of water to have a strong lateral flow component and divert soil water into the overhang (upper) drain system in this plot. The underlying cobble layer made up the biointrusion barrier and consisted of a 91-cm-decp layer of cobble 


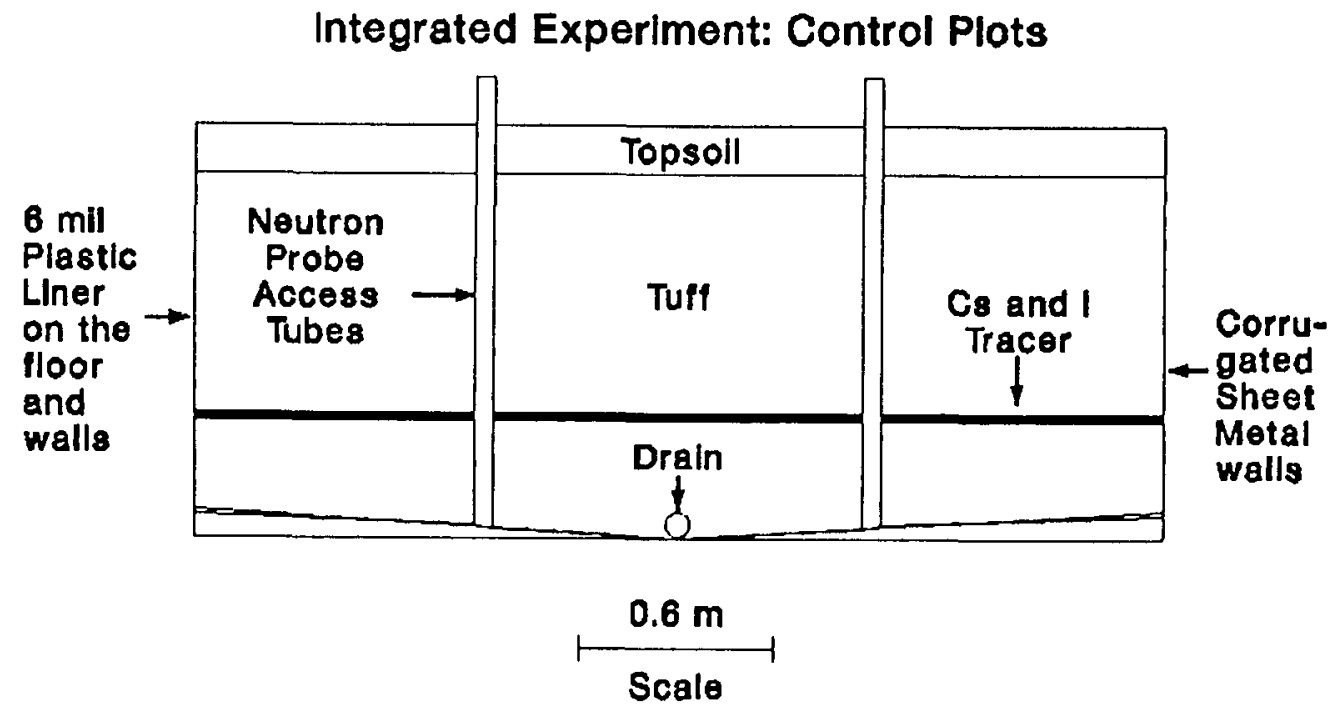

Fig. 2. Conventional ITP trench cap design.

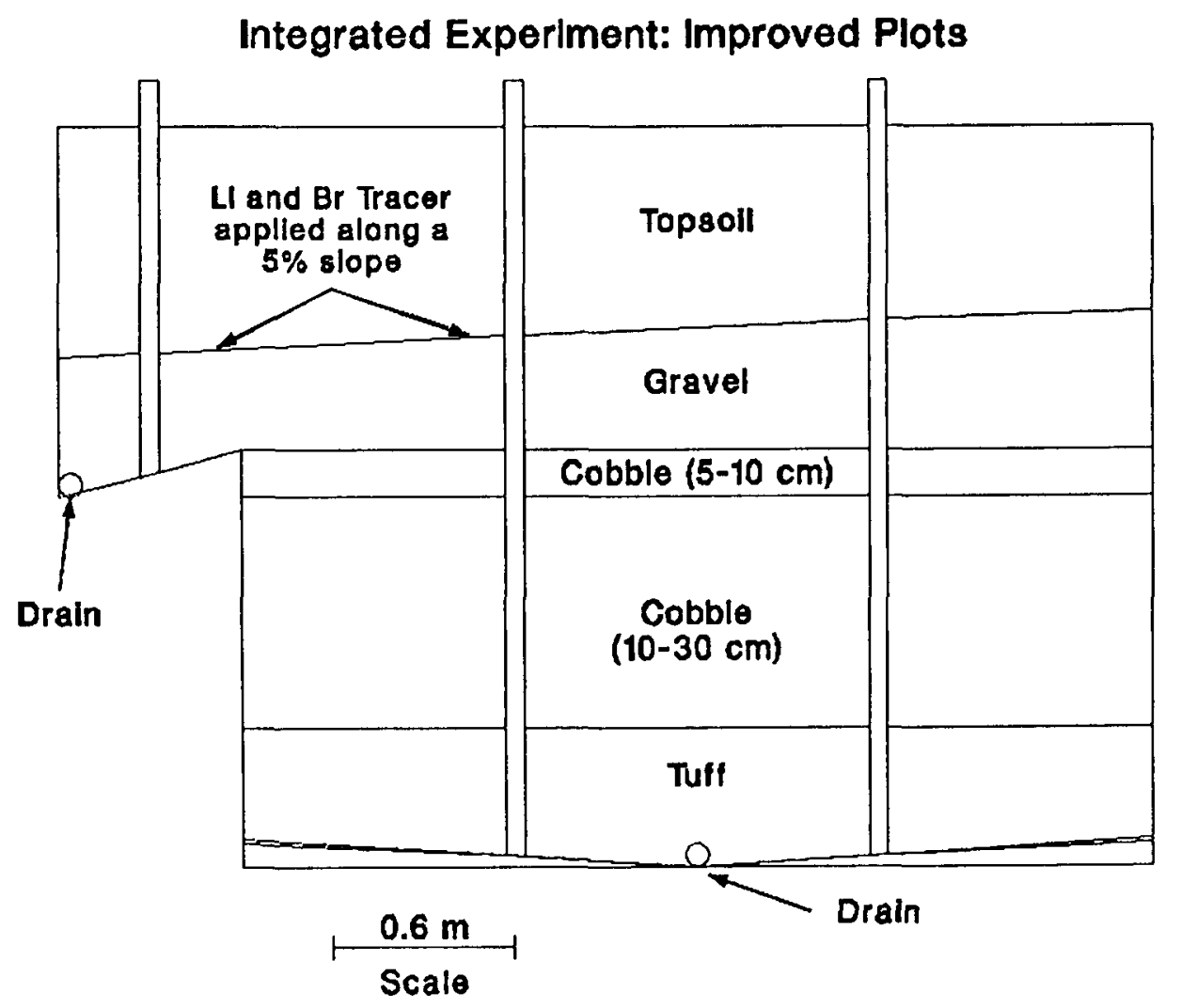

Fig. 3. Improved ITP trench cap design. 
with diameters ranging from about $10-30 \mathrm{~cm}$ (Fig. 3). This layer should minimize plant root intrusion because the spaces between the cobble are relatively free of soil and water. The cobble layer also should prevent most burrowing animals from penetrating the biointrusion barrier because the stones are too heavy to move. Cesium iodide tracer was applied to the surface of the crushed tuff immediately beneath the capillary-biointrusion barrier in the improved cover design. This layer, as with the conventional cover design, demarks the bottom of the trench cap.

Volumetric soil water content was measured at this field site with a neutron moisture probe (Campbell Pacific Nuclear Corp. Model 503, Pacheco, CA), which had been previously calibrated for the crushed tuff used in these experiments (Nyhan et al. 1983). Neutron moisture probe data were collected at six locations per plot on the conventional trench cap design $(20,40,80$, and $110 \mathrm{~cm})$ and at nine locations per plot on the Improved Plots (at depths of $20,40,60$, and $220 \mathrm{~cm}$ below the surface). These data were used to estimate the inventories of soil water in each of these cover designs as a function of time [the ds/dt term of Eq. (1)], as described previously (Nyhan et al. 1989b).

\section{B. Model Calibration Efforts}

The model calibration efforts and techniques used in this study have been previously described (Nyhan and Barnes 1989). Basically, the CREAMS model was calibrated for several experimental SLB scenarios at Area B at the Los Alamos National Laboratory, as well as for Control Plot 1 in the ITP experiment (Nyhan and Barnes 1989).

The modeling studies were conducted in two phases at Waste Disposal Area B. Initially, a series of CREAMS simulations were conducted to optimize values of hydrologic soil parameters. Then CREAMS simulations were conducted on all experimental scenarios at Waste Disposal Area B using optimized parameter estimates. Lane (1984) gives a range of possible values for each soil parameter required for CREAMS (saturated hydraulic conductivity, bare soil evaporation, porosity, field capacity, and wilting point). The optimum values were chosen by initially conducting a series of simulations to explore the capability of the models to reproduce observed profile-averaged soil moisture trends from 1983 to 1985 on the west control plot 11 at Waste Disposal Area B, which had a dense rabbitbrush cover, a standard landfill cover soil profile, and a two-year record of soil moisture measurements before to the start of the study (Nyhan et al. 1986).

The basic structure and initialization of the model for Waste Disposal Area B was accomplished using known site-specific data, actual daily precipitation totals for 1983-1985 and 20-ycar averages of air tcmpcrature and solar radiation for Los Alamos. Leaf area index (LAI) in 1983 and 1984 was estimated so as to agree with observed seasonality in growth patterns and LAI levels attained by herbaceous weeds in 1985. For 1985, estimates of LAI were based on field measurements on shrubs and herbaceous weeds. Instead of using recommended values for soil hydrologic parameters of the appropriate soil texture classes represented at Area B (Knisel 1980, Lane 1984, Schroeder et al. 1984), several simulations tested the effects of varying the parameters over the reported ranges on predicted average soil-moisture content.

First, average values of certain soil parameters (saturated hydraulic conductivity, field capacity, and wilting point) were used as recommended by Lane (1984) for the soil texture classes represented in the plot 11 soil profile. Second, the ranges suggested for the soil texture classes (Lane 1984) were tested. Third, the effect of using the measured saturated hydraulic conductivities of the specific soils on the site (Abeele 1984) was tested. Finally, after determining which parameter values maximized the fit between observed and predicted retention and drainage of soil water, the curve number was adjusted to obtain the best possible representation of infiltration of precipitation from summer storm events.

The performance of CREAMS in predicting soil moisture on plot 11 at Waste Disposal Area B, as wcll as in the ITP experiment, was assessed similarly (Fig. 4). The observed field values were averaged over all measurement depths and over all locations on each plot (plot 11 at Waste Disposal Area B and Control Plot 1 in the ITP experiment) to give one mean soil moisture value for each measurement time. Best fit of the predicted to the observed soil-moisture patterns was assessed by the standard technique of regression analysis with the aim of maximizing the coefficient of determination $\left(\mathrm{R}^{2}\right)$ and optimizing the slope and intercept of the regression line to approach the equal value line (Pathak et al. 1984). In the ITP 


\section{Model Performance Evaluation Technique}

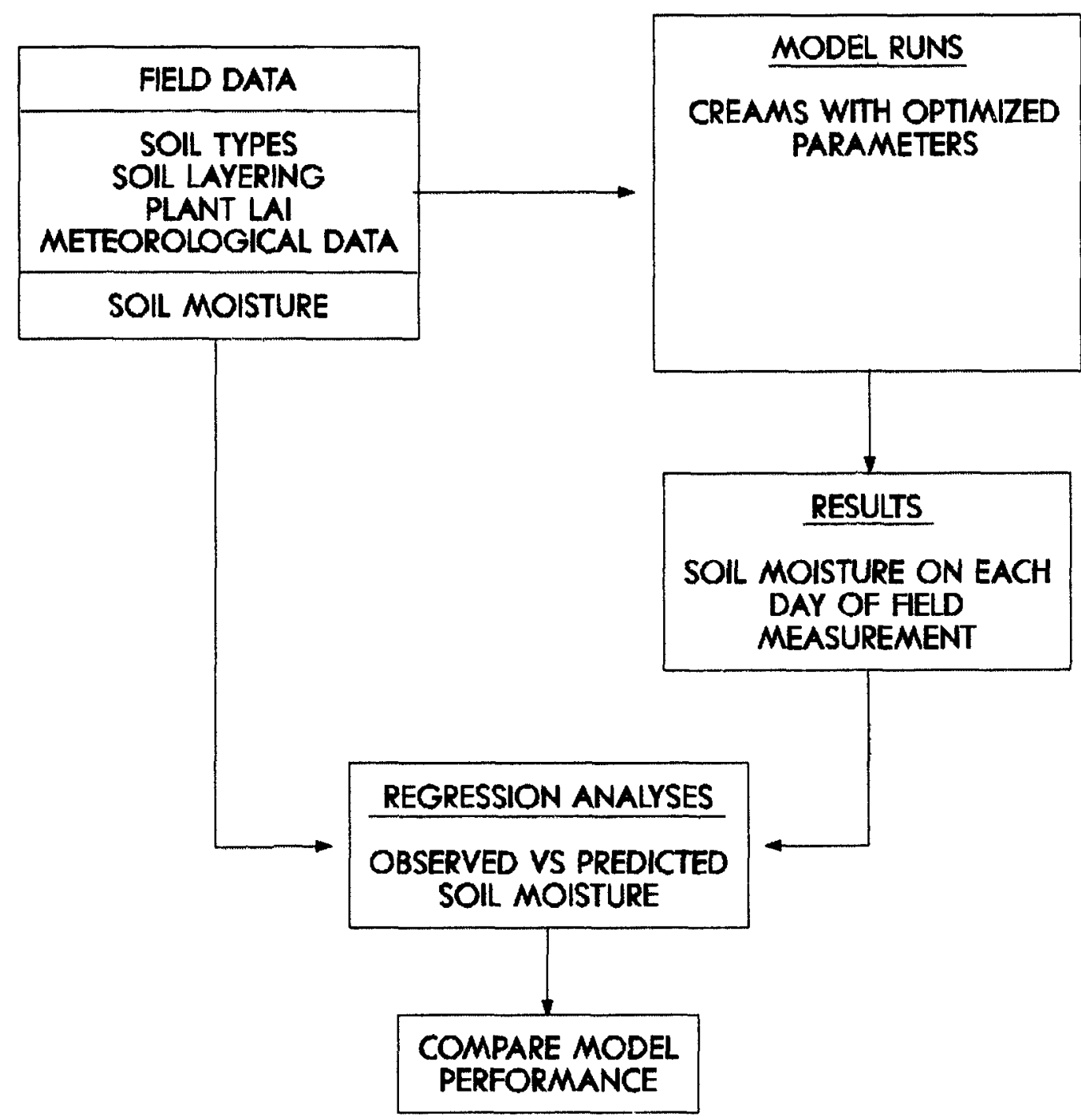

Fig. 4. Flow chart of model optimization technique.

experiment, the other terms of the water balance equation were also compared with CREAMS predictions of ET and L.

In the process of finding the parameters that produced the optimum CREAMS simulation (summarized in Tables II and III), we quickly made several important observations early in the series of over 
250 CREAMS simulations that were performed using the Control and Improved Plot scenarios. These observations are summarized in the following subsections.

1. Saturated Hydraulic Conductivity. The first observation was that the laboratory-derived values for the saturated hydraulic conductivity $(\mathrm{K})$ were vastly different than the $\mathrm{K}$-values suggested to be used in CREAMS for the texture of our topsoil (Lane 1984). The laboratory-derived $\mathrm{K}$ estimates for the topsoil ranged from 6.56 to 17.7 in./h (Nyhan and Barnes 1989), whereas Lane suggested K-values of 0.07 in./h for a silty clay loam, with a range in $\mathrm{K}$ values of 0.06 to $0.08 \mathrm{in} . / \mathrm{h}$. Research performed at the University of Texas at Austin (Day and Daniel 1985) pointed out 1000-fold differences in $\mathrm{K}$ values produced in the laboratory versus those determined in the field for fine-textured soils, where $\mathrm{K}$ was equal to $0.01 \mathrm{in} . \mathrm{h}$. Obviously, using the laboratory-derived $\mathrm{K}$ values for the CREAMS model greatly overestimate $\mathrm{k}$ number field conditions.

We ultimately had to make a compromise to derive an optimum parameter value for $\mathrm{K}$ for use in CREAMS. The only field data that we could use for this purpose for the Control Plot were from an erosion plot study (Nyhan and Lane 1986a) involving a trench cap design similar to the configuration in the ITP Control Plots. An estimate of $\mathrm{K}$ was derived from the very wet soil-surface rain simulator run (average of two plots) by subtracting the peak runoff discharge rate of $2.30 \mathrm{in} . / \mathrm{h}$ from the applied rainfall rate of $2.36 \mathrm{in} . / \mathrm{h}$, resulting in a $\mathrm{K}$ estimate of $0.06 \mathrm{in} . / \mathrm{h}$. Now we were more confident that our laboratory-derived estimates of $\mathrm{K}$ were at least two orders of magnitude too high (Nyhan and Bames 1989). However, CREAMS simulations with values of $\mathrm{K}$ in excess of $0.02 \mathrm{in.} / \mathrm{h}$ resulted in far more leachate production than we actually observed. Becausc CREAMS simulations in which $\mathrm{K}$ was set equal to 0.01 in./h resulted in too little leachate production (i.e., only $0.793 \mathrm{in.}$ for 1985) relative to what we observed for $\mathrm{K}$ equal to $0.02 \mathrm{in.} / \mathrm{h}$ (i.e., $1.13 \mathrm{in}$. for 1985 ), we compromised on a $\mathrm{K}$ value of $0.02 \mathrm{in.} / \mathrm{h}$.

Similar considerations were used in the estimation of $\mathrm{K}$ for the Improved Plot 2 scenario. Because the CREAMS model was not developed for modeling layered systems (Knisel 1980), the Improved Plot design was calibrated using field data from the soil layer above the capillary barrier only (Fig. 3 ). The Improved Plot cover profile (Fig. 3) contained a larger amount of fine-textured topsoil in the SLB profile than the Control Plot (Fig. 2), so that the value of $\mathrm{K}=0.02 \mathrm{in} . / \mathrm{h}$ derived for the Control Plot was not adequate for CREAMS simulations of the Improved Plot design (leachate production predictions were grossly overestimated). A final $\mathrm{K}$ estimate of $0.006 \mathrm{in} . / \mathrm{h}$ (Table III) was arrived at by running sevcral CREAMS simulations and matching observed and predicted seepage terms until this optimum $\mathrm{K}$ value was determined I decided that this final $\mathrm{K}$ value was small enough to adequately reflect the increased clay and silt concentrations over those found in the Control Plot soil profiles.

2. Bare Soil Evaporation Parameter. The second major observation we made concerned the value of the bare soil evaporation parameter $(C)$ used in CREAMS. Actual soil evaporation in CREAMS is computed in two stages. In the first stage, evaporation that occurs immediately after a rain is limited only by the energy available at the soil surface and is equal to potential soil evaporation. Second stage evaporation occurs after the soil has visibly dried and is generally described as the soil-limiting phase. This second phase is usually modeled by plotting evaporation rate versus the square root of time and determining the constant $\mathrm{C}$ (change in cumulative soil evaporation with a change in square root of time). Thus, $C$ is dependent on soil water transmission characteristics and varies directly with the hydraulic conductivity of the soil at -0.1 bar soil matric potential (Ritchie 1972) and also with soil temperature (Jackson et al. 1976). Thus, Lane (1984) has summarized the literature values of $\mathrm{C}$ for different soil texture classes, with suggested average $C$ valucs ranging from about $4.5 \mathrm{~mm} / \mathrm{d}^{1 / 2}$ for silt loams to about $3.3 \mathrm{~mm} / \mathrm{d}^{1 / 2}$ for sands; i.e., silt loams have higher soil water transmission characteristics than sands.

The recommended average value (Lane 1984) of $\mathrm{C}$ for our silty clay loam topsoil in the ITP experiment was $3.8 \mathrm{~mm} / \mathrm{d}^{1 / 2}$, with a suggested range in values of from 3.15 to $4.32 \mathrm{~mm} / \mathrm{d}^{1 / 2}$. CREAMS simulations using values of $\mathrm{C}$ as large as these resulted in gross overestimates of evapotranspiration throughout each simulation year. Because evapotranspiration was measured in the ITP experiment, I estimated a value of $3.05 \mathrm{~mm} / \mathrm{d}^{1 / 2}$ to describe the bare soil evaporation parameter. A C value this small would normally be used as a minimal $C$ value for a sand or loamy sand (Lane 1984). However, the $60 \%$ gravel cover used on the surface of the Control Plots likely reduced bare soil evaporation sufficiently to justify our use of $20 \%$ lower $\mathrm{C}$ value than that suggested by Lane (1984). 
TABLE II. Optimized parameters for CREAMS simulation of soil-water storage on ITP control plot 1 .

Soils: $0-20 \mathrm{~cm}$, topsoil (silty clay loam)

20-128 cm, crushed tuff (loamy sand)

Slope: $0.5 \%$

Plant Parameters

Rooting Depth: $128 \mathrm{~cm}$ (51 in.)

Winter Cover Factor: 0.50

LAI Distribution:

\begin{tabular}{cccc} 
Time (days) & 1985 & 1986 & 1987 \\
\hline 1 & 0.00 & 0.00 & 0.00 \\
91 & 0.00 & 0.00 & 0.00 \\
121 & 0.05 & 0.05 & 0.05 \\
152 & 0.80 & 0.50 & 0.36 \\
180 & 1.00 & 0.90 & 0.30 \\
210 & 0.90 & 0.60 & 0.40 \\
240 & 0.60 & 0.25 & 0.20 \\
280 & 0.25 & 0.01 & 0.10 \\
310 & 0.00 & 0.00 & 0.00 \\
366 & 0.00 & 0.00 & 0.00
\end{tabular}

Soil Parameters:

Saturate hydraulic conduclivity: $0.051 \mathrm{~cm} / \mathrm{hr}$

Bare soil evaporation parametcr: $3.05 \mathrm{~mm} / \sqrt{\mathrm{d}}$

SCS Curve Number: 65

Porosity: topsoil: 0.42

tuff: 0.35

Field Capacity: topsoil: 0.27

tuff: 0.18

Wilting Point: topsoil: 0.17

tuff: 0.09

3. Leaf Area Index. The distribution of LAI with time was also a CREAMS parameter which was estimated and not directly measured. The only ficld data we had involved biomass estimates in the ITP experiment for one point in time. Using the temporal distributions of LAI at Area B, and color photographs taken on the ITP plots with time, an initial set of LAI values was estimated. A final set of LAI values was derived (Tables II and III) by further optimizing the initial set of LAI values using observed versus measured field estimates of evapotranspiration and leachate production. 
TABLE III. Optimized parameters for CREAMS simulation of soilwater storage on ITP control plot 2.

Soils: $0-71 \mathrm{~cm}$, topsoil (silty clay loam)

Slope: $0.5 \%$

Plant Parameters

Rooting Depth: $71 \mathrm{~cm}(28$ in.)

Winter Cover Factor: 0.50

LAI Distribution:

\begin{tabular}{cccc} 
Time (days) & 1985 & 1986 & 1987 \\
\hline 1 & 0.00 & 0.00 & 0.00 \\
91 & 0.00 & 0.00 & 0.00 \\
121 & 0.50 & 0.25 & 0.50 \\
152 & 1.00 & 0.70 & 0.80 \\
180 & 0.80 & 0.70 & 0.60 \\
210 & 1.80 & 0.50 & 0.40 \\
240 & 1.20 & 0.20 & 0.30 \\
280 & 0.50 & 0.08 & 0.30 \\
310 & 0.10 & 0.03 & 0.00 \\
366 & 0.00 & 0.00 & 0.00
\end{tabular}

Soil Parameters:

Saturate hydraulic conductivity: $0.051 \mathrm{~cm} / \mathrm{hr}$

Bare soil evaporation parameter: $3.05 \mathrm{~mm} / \sqrt{\mathrm{d}}$

SCS Curve Number: 65

Porosity: topsoil: 0.35

Field Capacity: topsoil: 0.22

Wilting Point: topsoil: 0.11

\section{Simulation Results}

The results of the CREAMS simulations with optimized parameters and the field data for the ITP experiment are presented in Figs. 5 and 6 . The average volumetric water content of the entire soil profiles of Control Plot 1 and Improved Plot 2 are described as a function of time from January 1985 through late 1987. The data generally show that CREAMS underpredicts soil water storage in both of the landfill cover designs (Figs. 5 and 6). When the predicted and observed soil water data were compared point for point by linear regression analysis (Figs. 5 and 6), several underpredictions and overpredictions were observed. However, using the coefficient of determination as a measure of the goodness of fit, CREAMS predicts soil moisture with acceptable accuracy $\left(R^{2}=0.70\right.$ for the Control Plot and $R^{2}=0.87$ for the Improved Plot). The values of the intercepts in the regression equation are not significantly different from zero, and 


\section{ITP Contral Plot 1 . \\ Volumetric soll water content versus time}
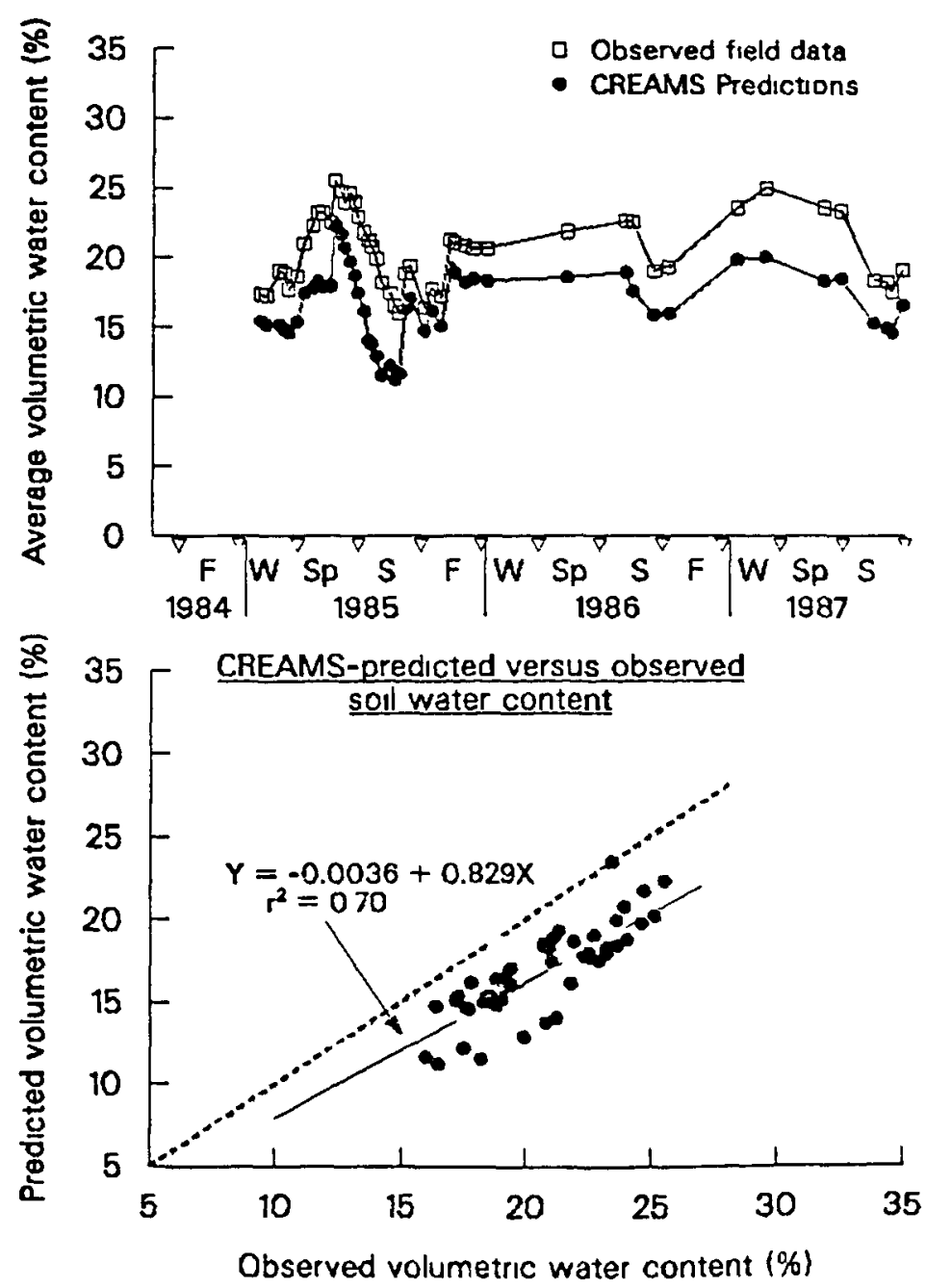

Fig 5. CREAMS-predicted and observed soll moisture on ITP Improved plot 1 as a function of ume (1985-1987)

the slope of the regression equation has a value close to unity (0.8289 and 0.706$)$ with a standard error of only 0.080. However, as with the Area B data (Nyhan and Barnes 1989), the variability is sull relatively high, with only $70 \%$ to $87 \%$ of the variability in observed soll water content being explained by the model algorithms

In addition, the observed and predicted evapotranspiration and seepage were also compared to further evaluate CREAMS predictive capabilities. For the two full years of field data where we could make comparisons, the observed total annual evapotranspiration for 1985 and 1986 was 24.73 and $20.24 \mathrm{~m}$., respectively. CREAMS predicted that 2364 and 21.77 in of evapotranspiration would occur in 1985 and 1986 , respectuvely, which agreed very well with the observed values on the Control Plot. The two periods of time when leachate was produced in the Control Plots were in May 1985, as well as December 1986 through May 1987. The CREAMS predictions of leachate production were $1.11 \mathrm{in}$. in May-June 1985 (0 22 in. observed in May), $0.46 \mathrm{in}$. in November-December 1986 ( 0.48 in. observed in December), and $1.18 \mathrm{in}$. in January-March 1987 (3.22 in. observed from January-May). In summary, the model predicted that a total of $2.75 \mathrm{in}$. of seepage would occur over the penod of the field study and a total of $3.92 \mathrm{nn}$. was 

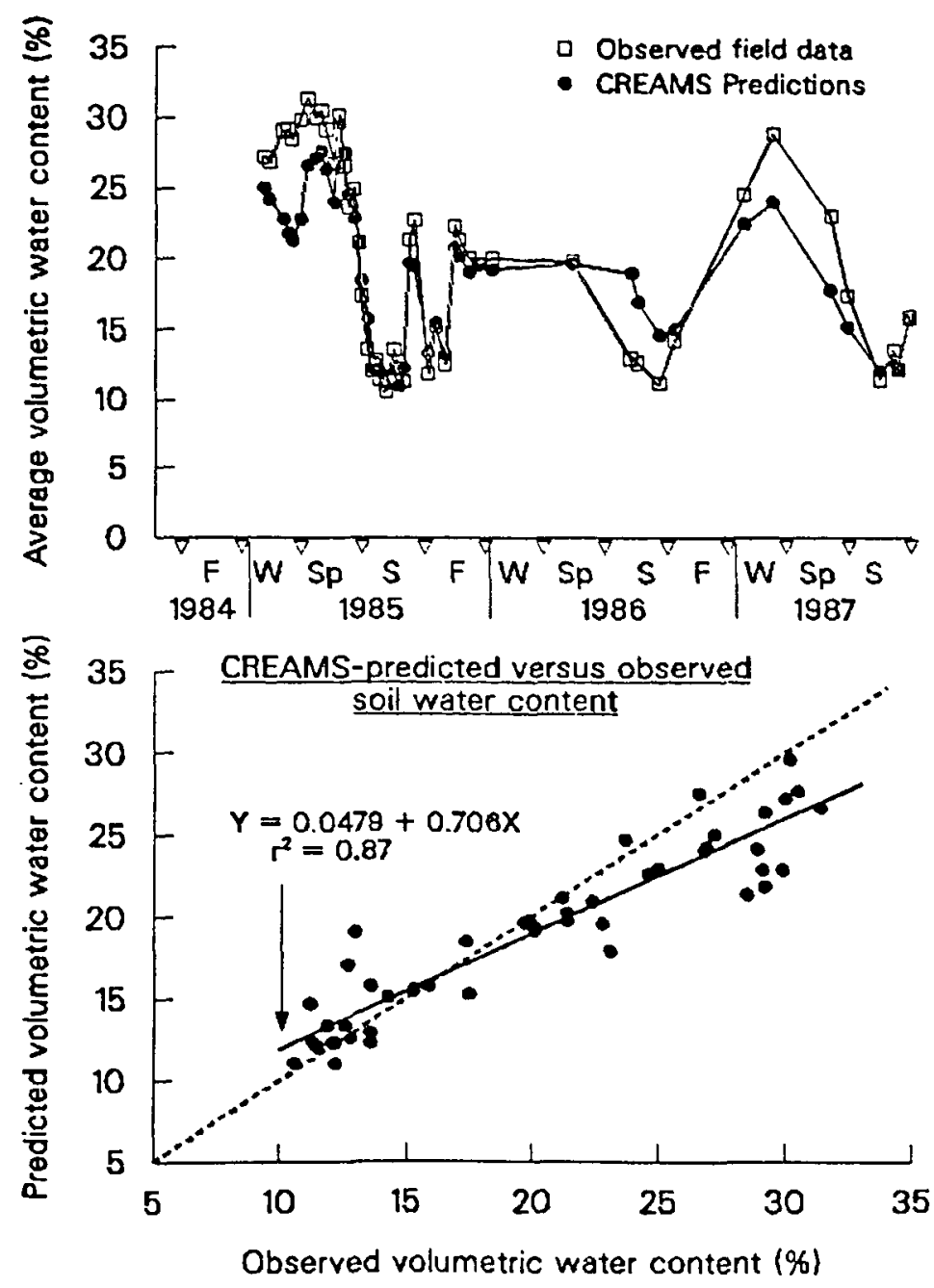

Fig. 6. CREAMS-predicted and observed soil moisture on ITP improved plot 2 as a function of time (1985-1987).

observed to occur in the Control Plots in the field. Thus, in terms of total seepage that occurred, $70 \%$ of the leachate production that actually occurred in the field was predicted by CREAMS, analogous to the $70 \%$ value we came up with between observed versus predicted soil water content.

\section{PROTOCOL FOR EXTRAPOLATING CREAMS CLIMATIC FACTORS TO OTHER WASTE SITES AT LOS ALAMOS}

Now that the model calibration results have been described in the previous section of this replort, the remainder of the report can deal with the use of the calibrated versions of the CREAMS model to address waste management issues within the boundaries of the Los Alamos NationalLaboratory. Thus, because the climatic factors used in CREAMS vary over the Laboratory boundaries, the extent of these variations needs to be evaluated in an effort to derive more generic CREAMS recommendations for SLB within the Laboratory. 
Climatic data required by the CREAMS water balance model are daily rainfall, mean monthly temperature, and mean monthly solar radiation. As discussed earlier, precipitation is the input to the water balance equation and is used in the computation of all the other terms. Mean monthly temperature and mean monthly solar radiation are fitted in Fourier series and then interpolated to daily values for use in the evapotranspiration calculations.

A major problem with performing hydrologic modeling at a specific disposal area within the Laboratory is that long-term input climatic data are not specifically available for the landfill itself. Precipitation in the area usually increases with elevation and proximity to the Jemez Mountains. Thus, for the entire county, the precipitation records available from the Laboratory's Environmental Surveillance Group at the $S$ Site (TA-16) weather station (elevation of $2338 \mathrm{~m}$ ) represent the weather data collected closest to the Jemez Mountains, but these records are only available from 1977 (with the 1978 data missing). The next closest weather data have been collected at the Occupational Health Laboratory (OHL, TA-59), which is located at an elevation of $2248 \mathrm{~m}$, but is farther away from the Jemez Mountains. However, the OHL data base is excellent in that the weather records go back to 1911. The last weather station with a record of any substantial length (1965 to present) is for White Rock, located even further away from the Jemez Mountains and with an elevation of $1944 \mathrm{~m}$.

A triple mass plot of the precipitation data available from 1977 through 1987 was constructed to determine differences between the precipitation received at the S Site, OHL and White Rock stations (Fig. 7). This plot clearly shows that the temporal precipitation pattern at S Site is similar to that at OHL, but both of these stations receive diffcrent precipitation pattern than that observed in White Rock. The average annual precipitation received at the S Site station was 20.50 in., only $1.23 \mathrm{in}$. more than that observed at OHL for this time period. The White Rock station, in contrast, exhibited an annual average precipitation of only 12.80 in.

Past modeling experience has demonstrated that seasonal inputs of precipitation can have a big effect on water balance components, such as seepage. For example, two locations could potentially have the same annual precipitation, but the location having the largest winter precipitation would probably have a larger amount of seepage because vegetation on the site would probably be senescent at this time. Therefore, we also analyzed the precipitation data for seasonal differences (Fig. 8). The results of this analysis show that there are no significant differences in the scasonal pattern of precipitation among the three sites, but the White Rock station seems to receive substantially less precipitation from July through September than the other two stations.

Since performance requirements for site closure are specified for time periods of 100 years (Table I), we performed a graphical and statistical analysis of the annual precipitation data collected at OHL (Nyhan et al. 1989a). The statistically calculated values for the 10-yr, 100-yr and 200-yr events $(25.0,32.9$, and 35.0 in., respectively) matched the corresponding graphically-derived values for annual precipitation $(25.9,32.9$, and 35.0 in., respectively). We also calculated the $95 \%$ one-sided tolcrance intervals for these estimates (Table IV) to provide estimates of the variation about these mean values. The $95 \%$ tolerance intervals for the 10-yr, 100-yr and 200-yr annual cvents were 27.0, 36.8 and 41.3 in., respectively. The interpretation of this statistical analysis for the 100 -yr event, for example, is that $95 \%$ of all the 100 -year precipitation events will be less than 36.8 in., with the average 100-year event being 32.9 in.

Monthly air temperature data are also used as an input parameter in CREAMS. Although temperature data were not available from S Site (Fig. 9), we were able to make a comparison between the OHL and the White Rock stations. The average annual temperatures for OHL (1951-1980 data) and White Rock (1965-1987) were $48.2^{\circ} \mathrm{F}$ and $49.2^{\circ} \mathrm{F}$, respectively. The major seasonal temperature difference between these two locations seems to be that White Rock has relatively warmer summers. Thus, because there was such a small difference between White Rock and OHL, it was decided that it was safe to use the OHL temperature data to represent every landfill in the Laboratory. To be sure this assumption was valid, several CREAMS simulations were performed using the ITP Control Plot scenario (Table II) comparing water balance relationships and the White Rock monthly temperature distributions (Fig. 9). The results of onc set of simulations, in which the 1965 through 1986 daily precipitation data from OHL was used as an climatic input, showed 20-yr averages of 14.182 in. of ET and 4.849 in. of L using the OHL temperature data, with 14.203 in. of ET and 4.827 in. of L using the White Rock temperature data. 


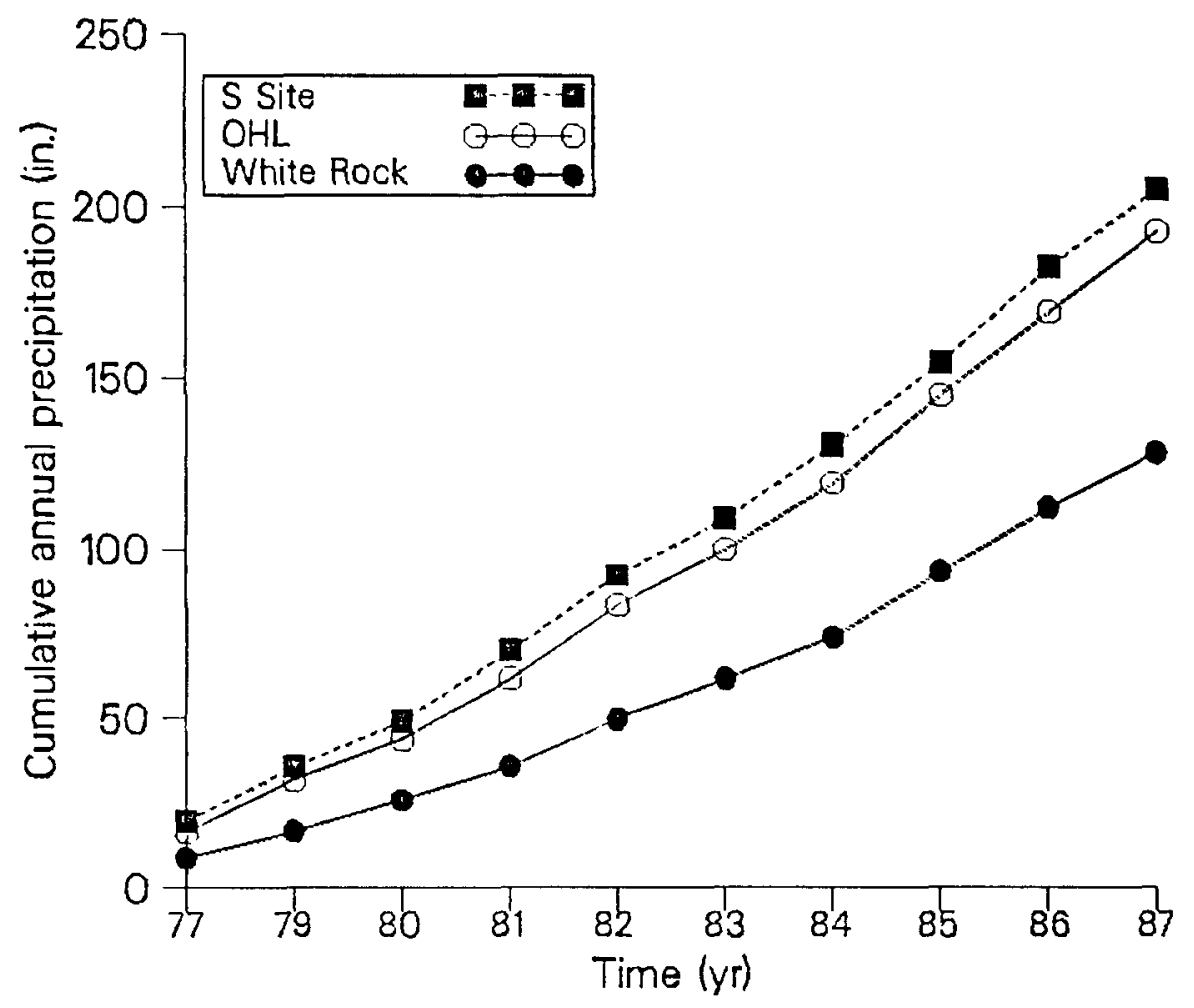

Fig. 7. Triple mass precipitation plot for three meteorological stations in Los Alamos County (1977-1987).

The CREAMS model also requires estimates of the monthly means of daily solar radiation (langleys/day), which are used to estimate evapotranspiration. This type of data is only collected at two weather stations within the Laboratory: at OHL and at a station at Waste Disposal Area G. The latter station contains incomplete meteorological data and has a much shorter period of record than the White Rock weather station (which is why the Area G climatic data was not used in this modeling study), but does seem to be similar to the White Rock station in terms of temperature and precipitation. Thus, an analysis of the solar radiation estimates at Waste Disposal Area $G$ should correlate adequately with those occurring at the White Rock weather station. An analysis of the solar radiation received at the OHL and Area $\mathrm{G}$ stations showed that the Area $\mathrm{G}$ station received about $5 \%$ greater solar radiation during a typical ycar than the OHL station. Using the same methodology and CREAMS simulation scenarios, which were used to evaluate spatial temperature fluctuations, the conclusion was made that it was safe to use the OHL long-term, continuous solar radiation data to represent every landfill within the Laboratory.

\section{USE OF CREAMS TO DESIGN CLOSURE COVERS FOR LOS ALAMOS LANDFILLS}

The investigations into climatic variability across the Laboratory presented in the previous section of this report were designed to reduce the number of CREAMS parameter combinations to be evaluated as landfill cover designs in this section of the report. For example, it was decided that it was safe to use the OHL temperature and solar radiation data to represent every landfill in the Laboratory. However, previous sensitivity analysis of the CREAMS model (Knisel 1980) has shown that small changes in the daily precipitation input term can result in very large fluctuations in model predictions of the other terms of the water balance equation [Eq. (1)]. Thus, the daily precipitation climatic parameter was identified from previous studies and our data analyses (Figs. 7 and 8) as an important parameter to be evaluated independently in this modeling study, so that both OHL and White Rock precipitation data were used to represent the Laboratory. 


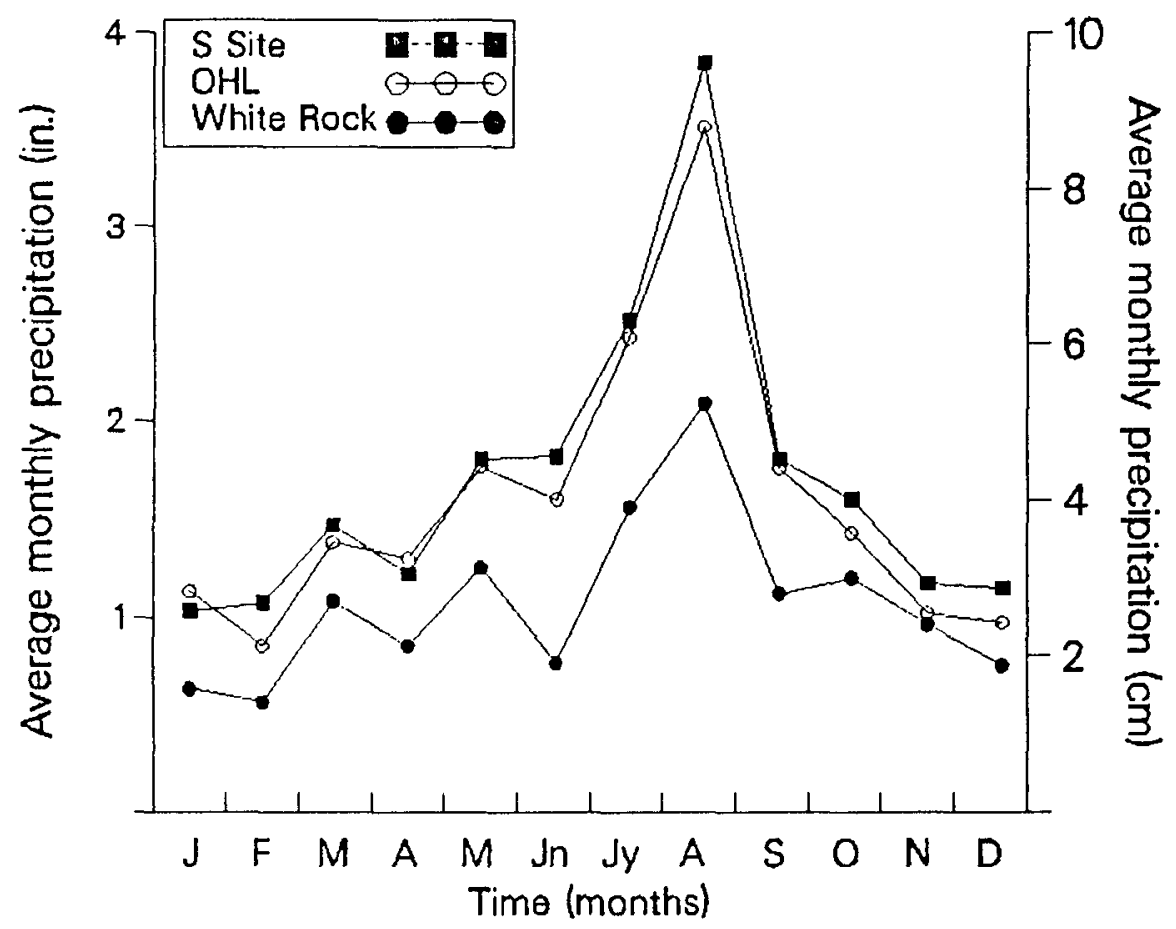

Fig. 8. Average monthly precipitation for three meteorological stations in Los Alamos County (1977-1987).

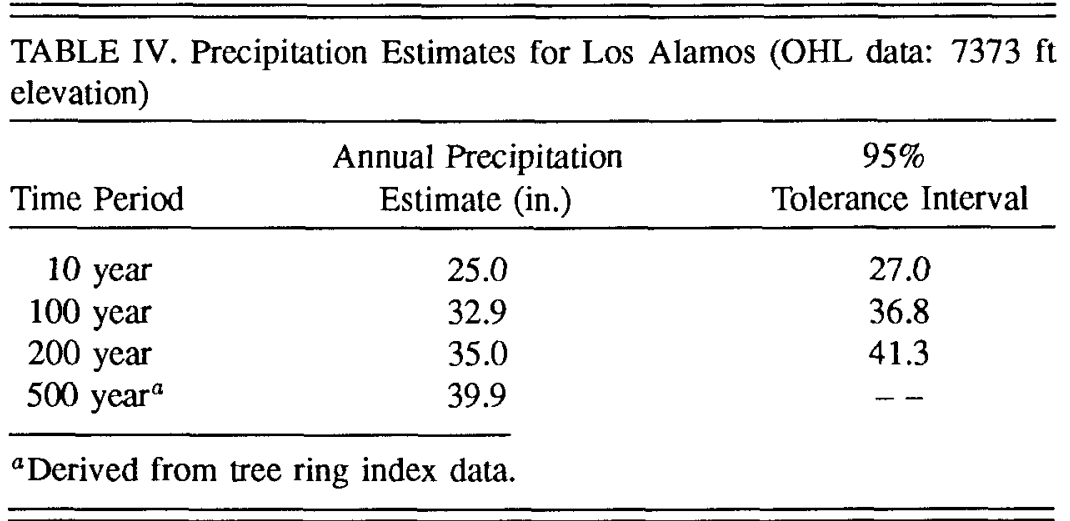




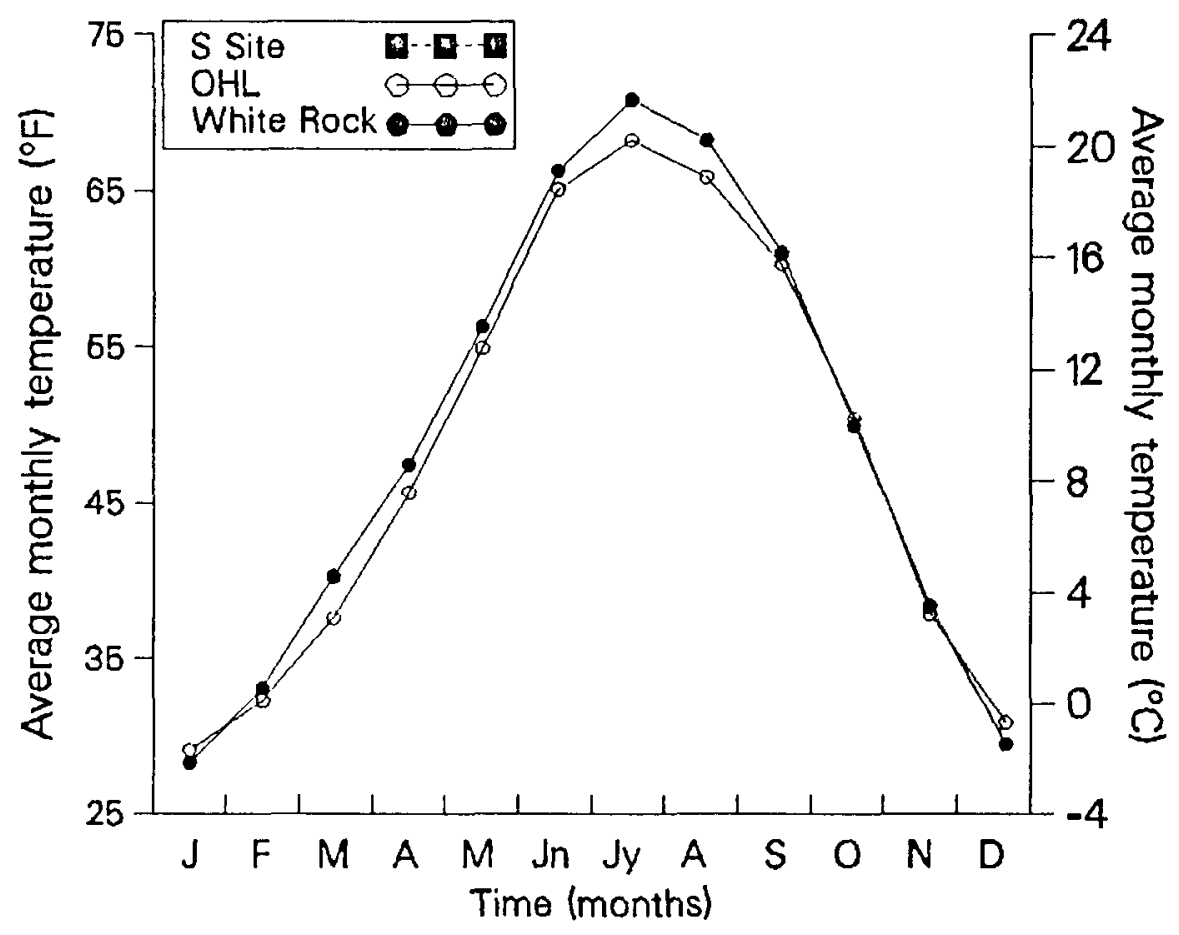

Fig. 9. Average monthly air temperature for meteorological stations in Los Alamos County (no data collected at S Site).

Using only the hydrologic portion of the CREAMS model, seepage production was predicted using our CREAMS-calibrated models for the Control Plot (Fig. 2, Table II) and Improved Plot (Fig. 3, Table III) cover designs. Seepage production was evaluated both for the average annual amount of seepage production in a 20-yr period of record (1965 through 1986, excluding 1979 and 1980, for which there are incomplete precipitation records at the White Rock weather station), and for the maximum amount of seepage predicted to occur in any 1 year in the 20 -yr period. Seepage production was evaluated as functions of all combinations of

1. vegetative cover at the landfill surface (bare soil conditions versus a plant cover of range grasses used in the ITP experiment)

2. daily precipitation occurring at the White Rock versus the OHL weather station,

3. runoff curve number $(\mathrm{CN})$ values of 65 and 90 , and

4. depth of the landfill cover, involving CREAMS simulations of cover depths of $0.305,0.457$, $0.610,0.914,1.524,2.134$, and $2.515 \mathrm{~m}$.

The results of this set of over 100 CREAMS simulations are presented in Figs. 10-13 for simulations with $\mathrm{CN}$ equal to 65, and in Figs. 14-17 for the simulations involving a $\mathrm{CN}$ value of 90 . The effect of varying each parameter on the simulated values of percolation is discussed in the following subsections.

\section{A. Effects of Vegetative Cover and Trench Cap Thickness}

The three main descriptors of the influence of begitation in CREAMS are (1) the LAI (the ratio of projected leaf surface are to the unit area of the soil), (2) plant rooting depth, and (3) the winter-cover factor.

Seasonal LAI data are summarized in Table $\mathrm{V}$ for the CREAMS user, and additional field data are presented elsewhere for Area B at Los Alamos (Nyhan and Barnes 1989). Many of the data in Table V are estimated because is is difficult and time consuming to measure this parameter. These data were proposed 


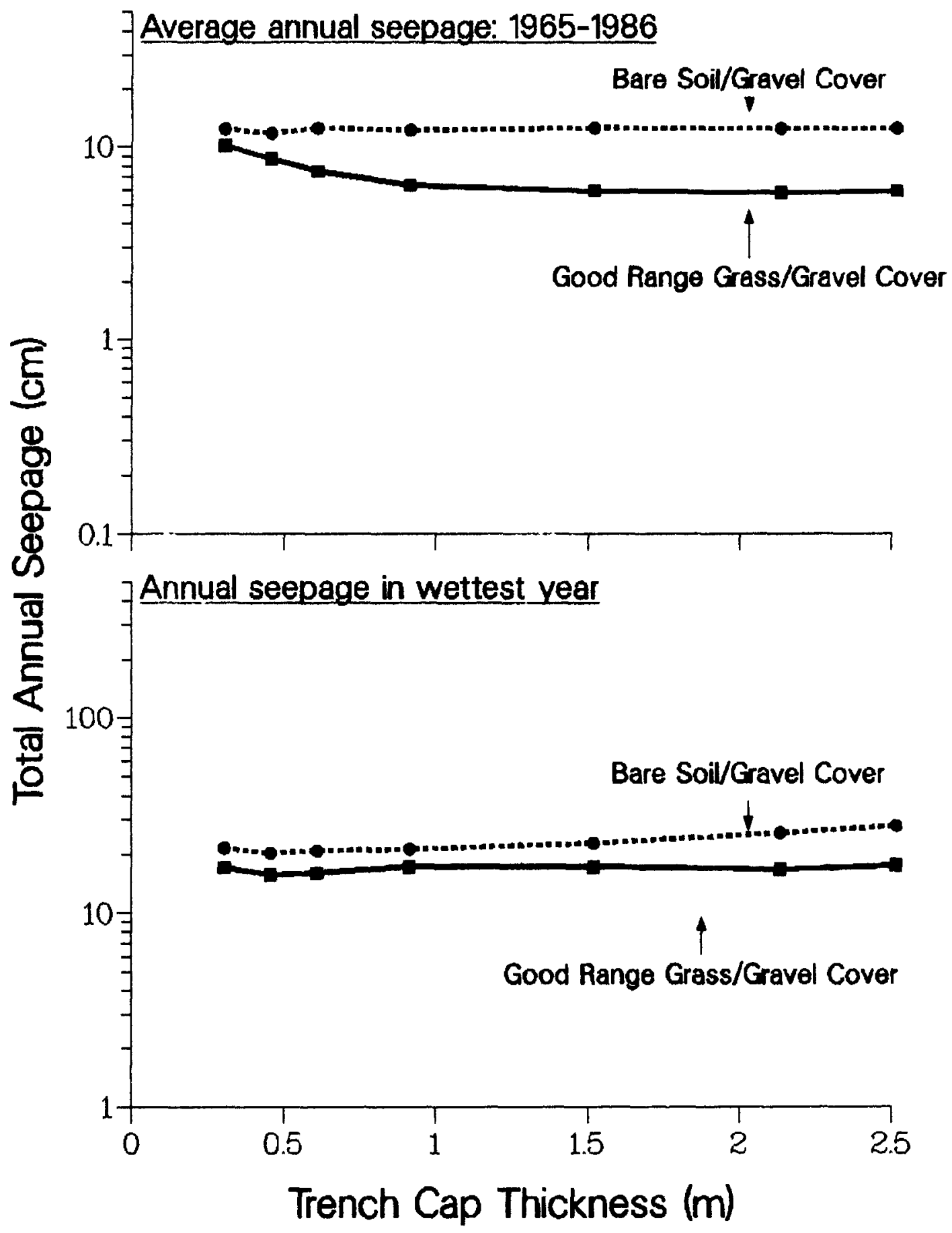

Fig. 10. CREAMS 20 yr simulation usıng OHL precipitation data base for ITP Control Plot cap design $(\mathrm{CN}=65)$ 


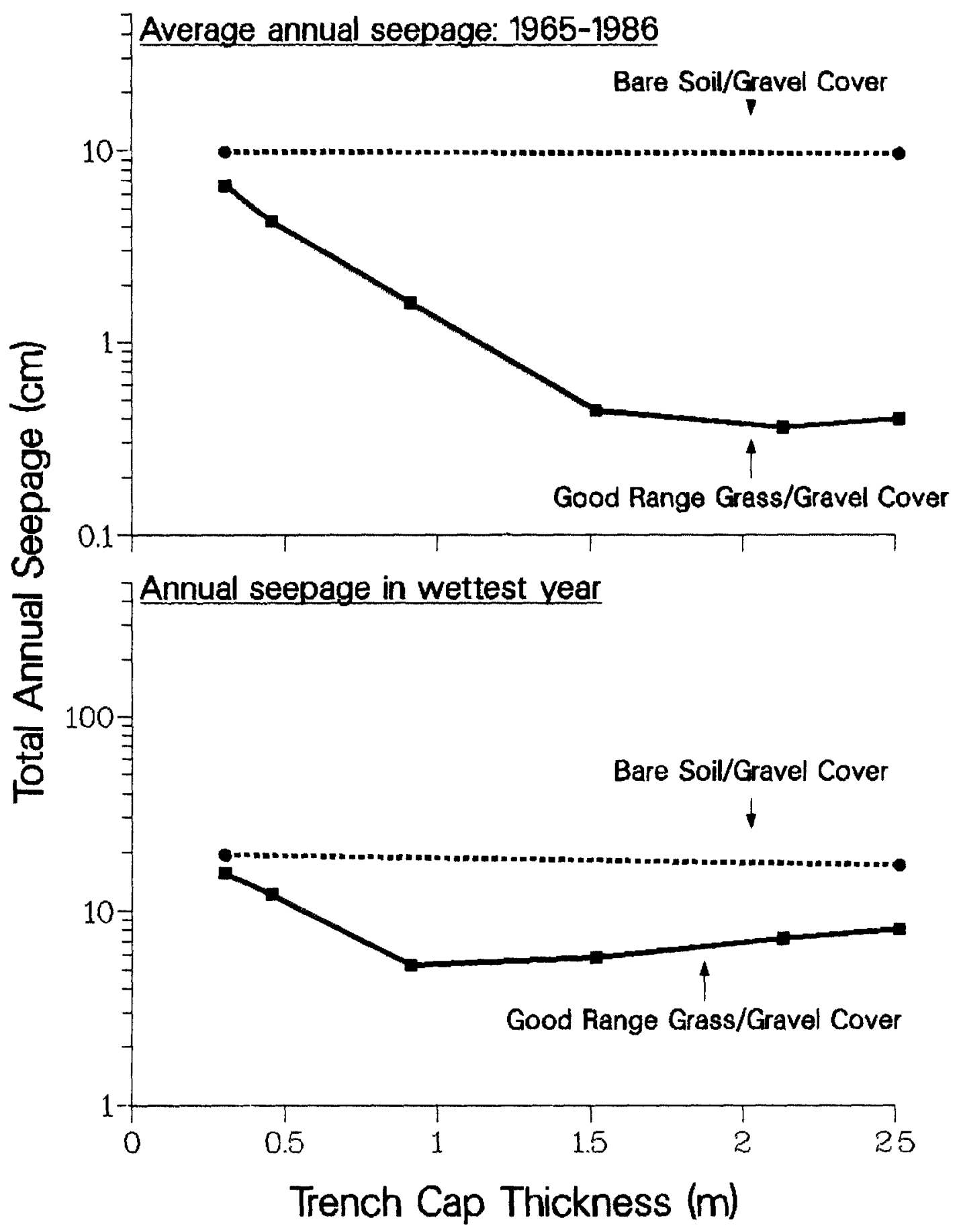

Fig. 11. CREAMS 20-yr simulation using OIL precipitation data base for ITP Improved Plot cap design $(\mathrm{CN}=65)$. 


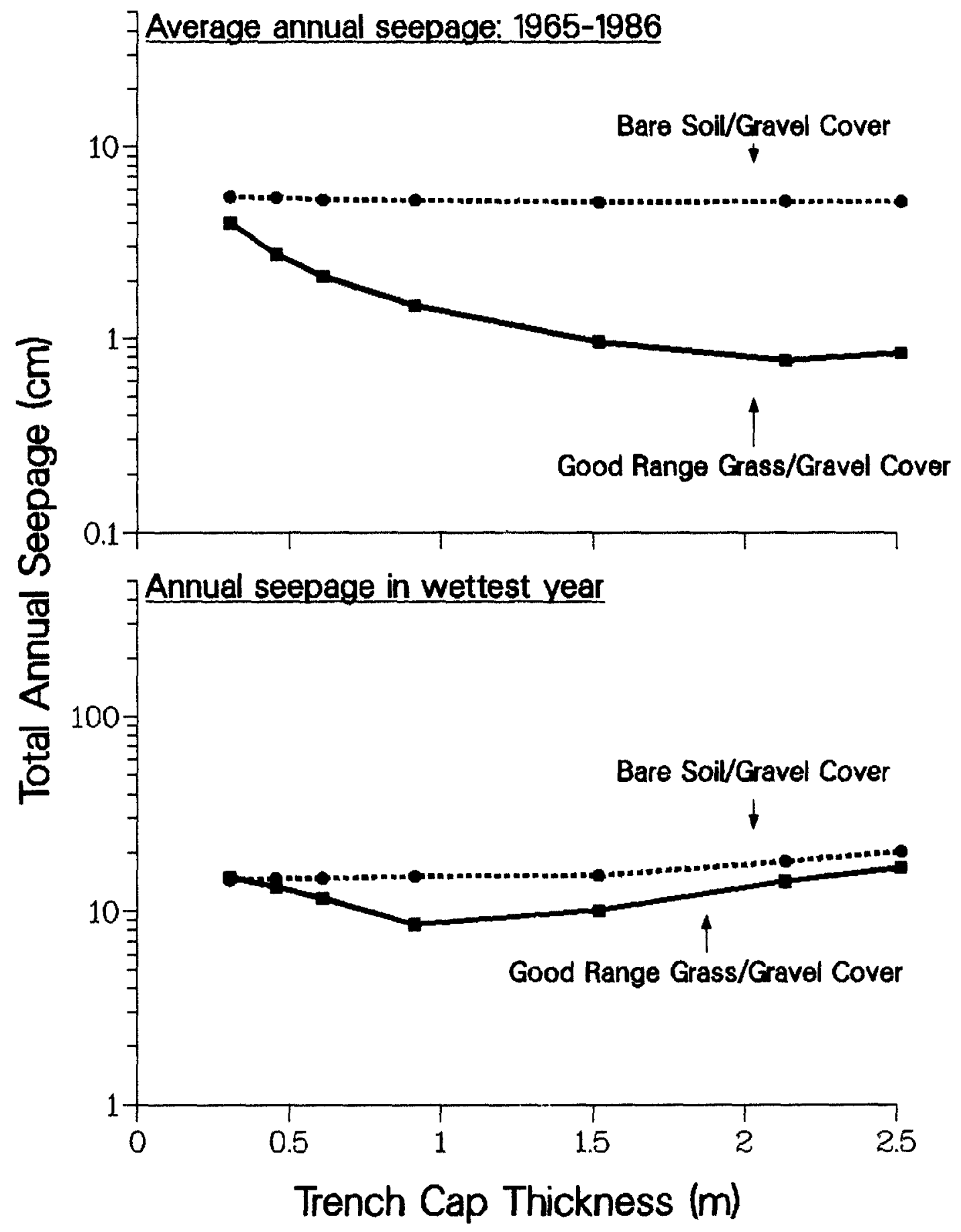

Fig. 12. CREAMS 20-yr simulation using White Rock precipitation data base for ITP Control Plot cap design $(\mathrm{CN}=65)$. 


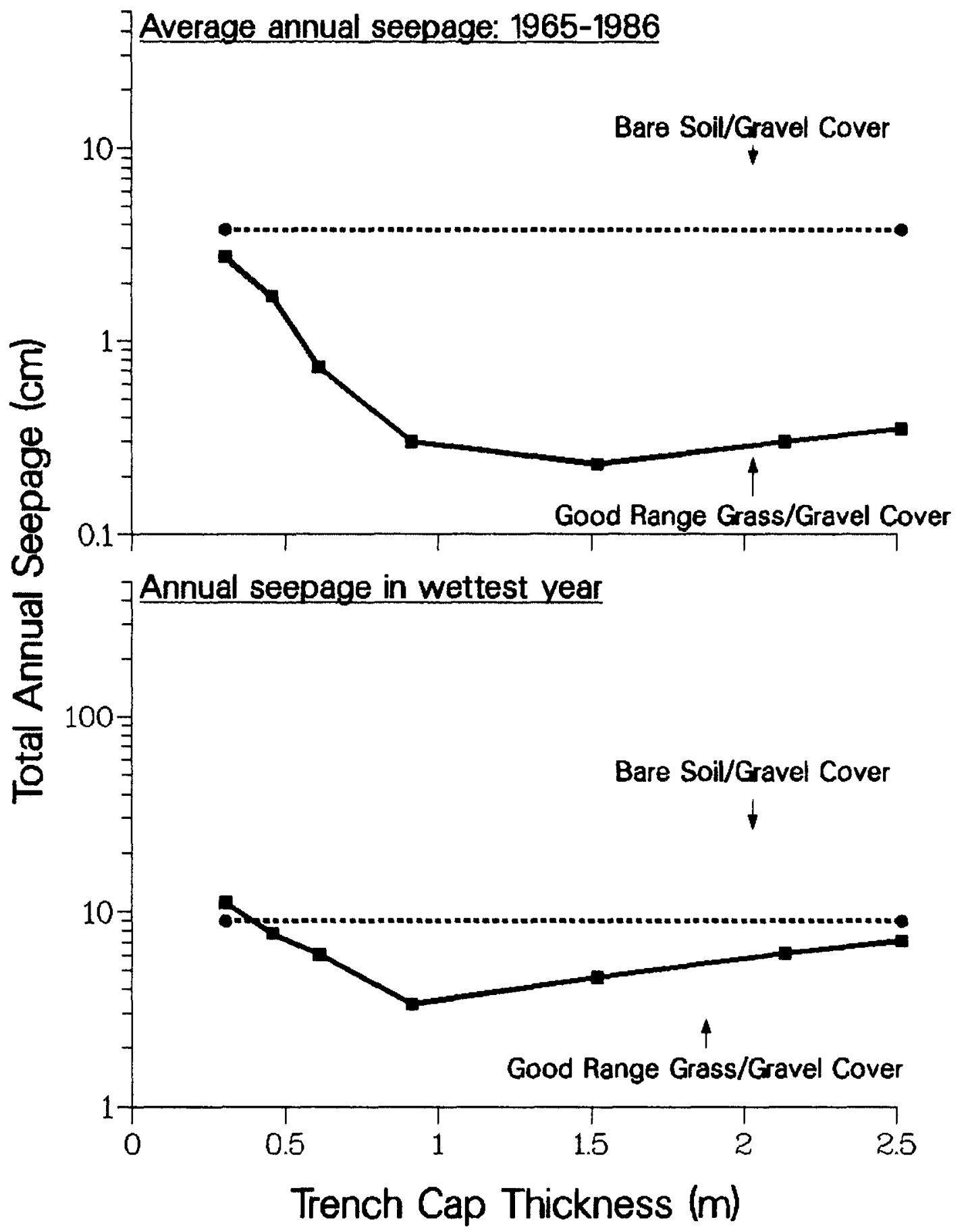

Fig. 13. CREAMS 20-yr sımulation usıng White Rock precipitation data base for ITP Improved Plot cap design $(\mathrm{CN}=65)$. 


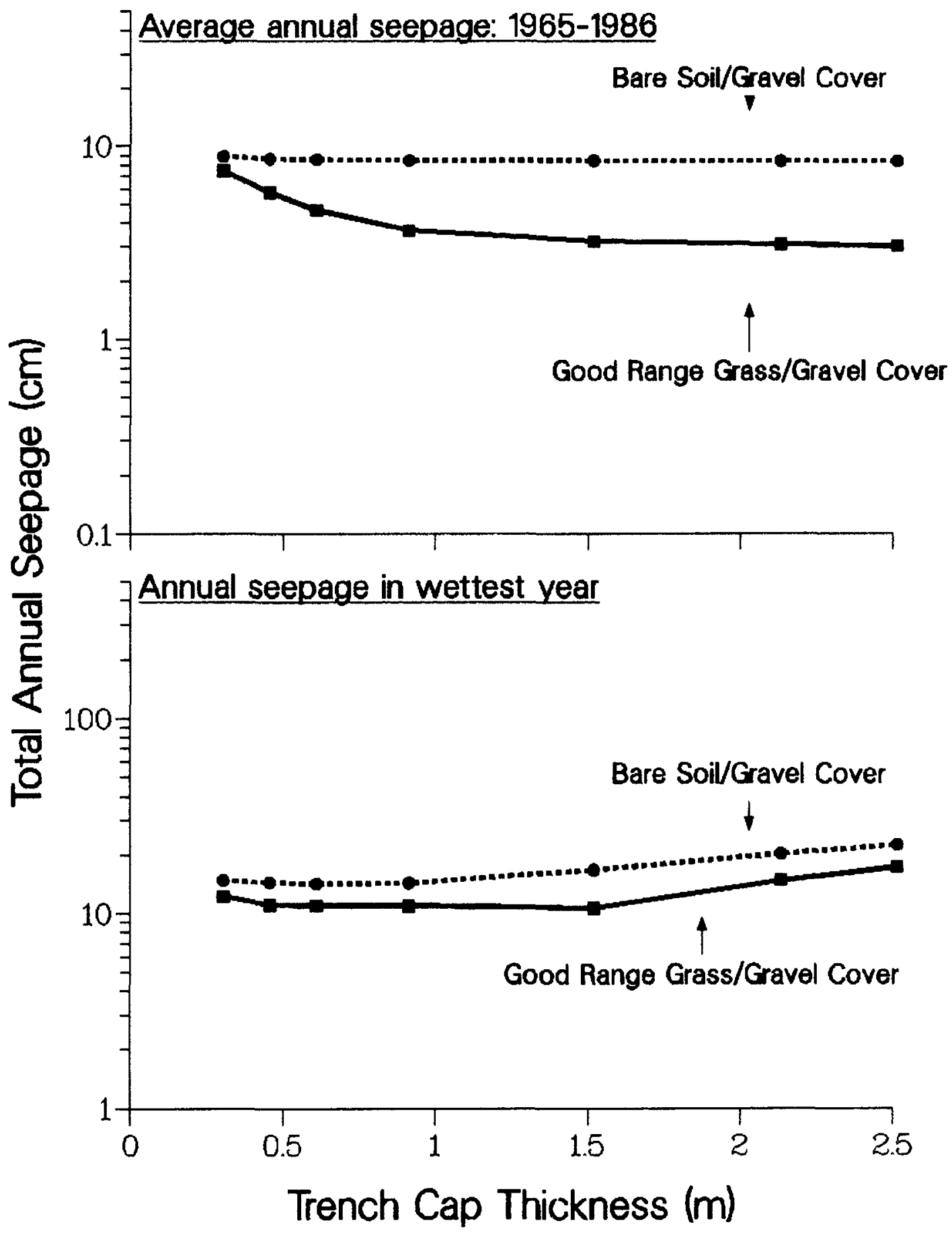

Fig. 14. CREAMS 20-yr simulation using OHIL precipitation data base for ITP Control Plot cap design $(C N=90)$. 


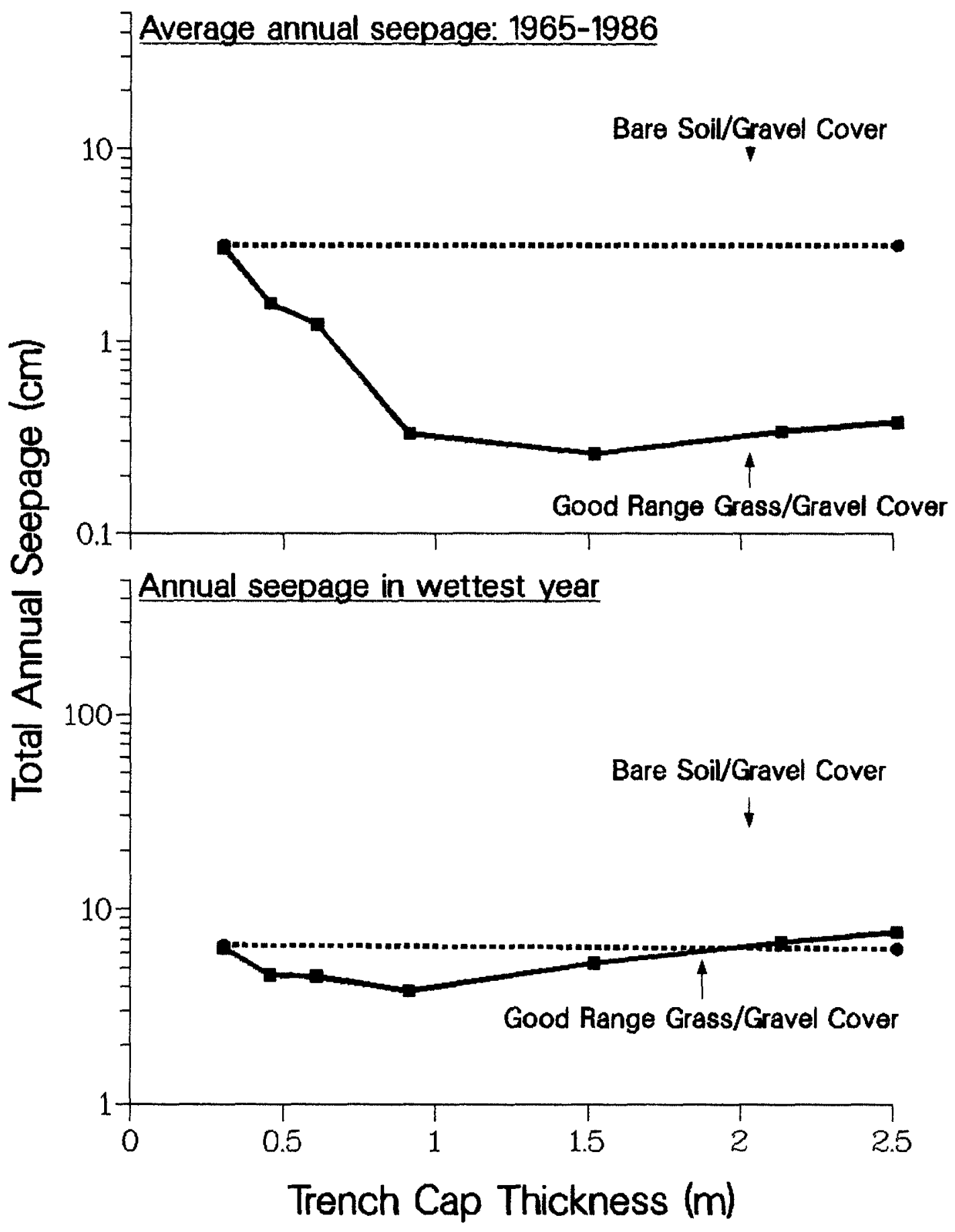

Fig. 15. CREAMS 20-yr sımulatıon using OHL precipitation data base for ITP Improved Plot cap desıgn $(\mathrm{CN}=90)$ 


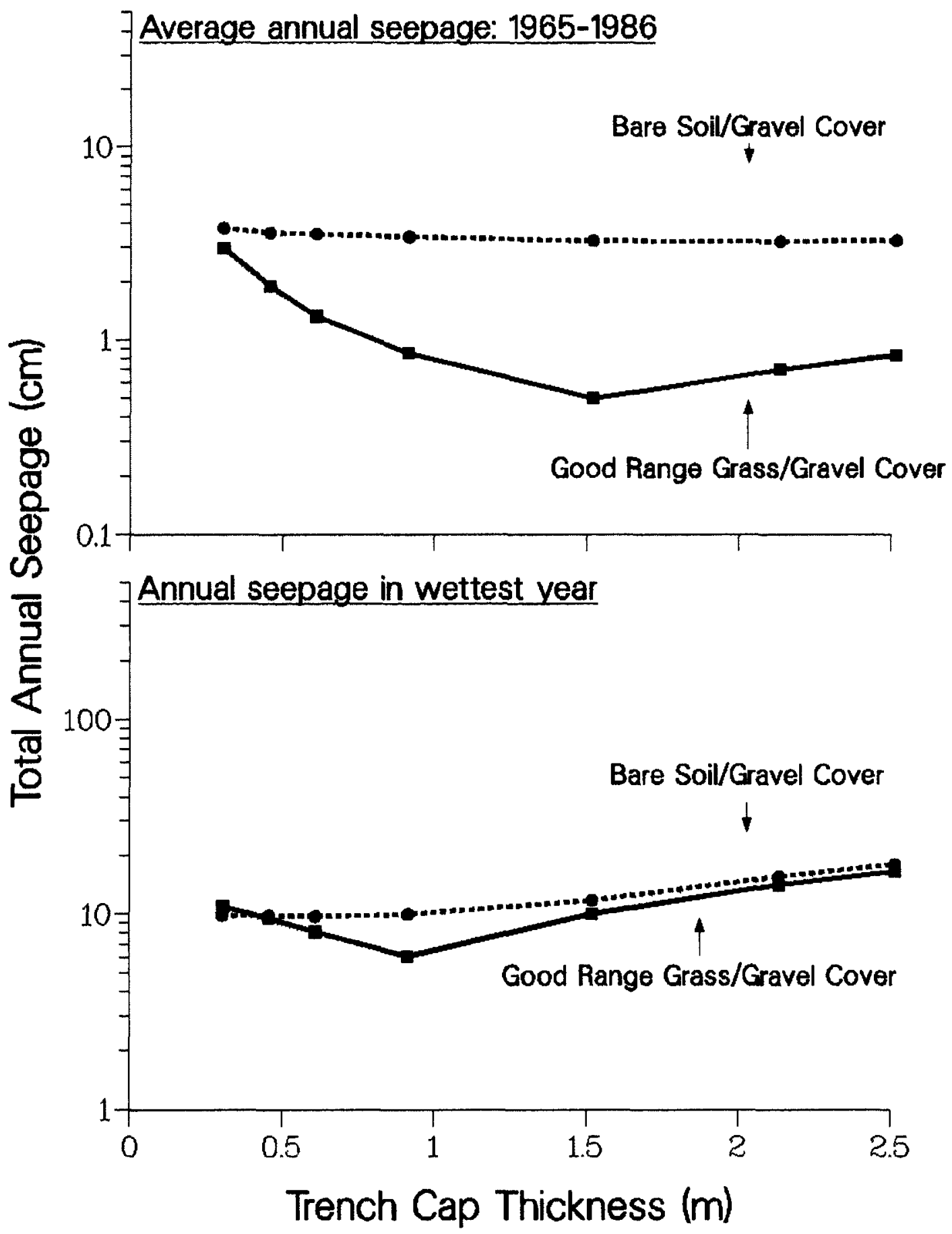

Fig. 16. CREAMS 20-yr simulation using White Rock precipitation data base for ITP Control Plot cap design $(\mathrm{CN}=90)$ 


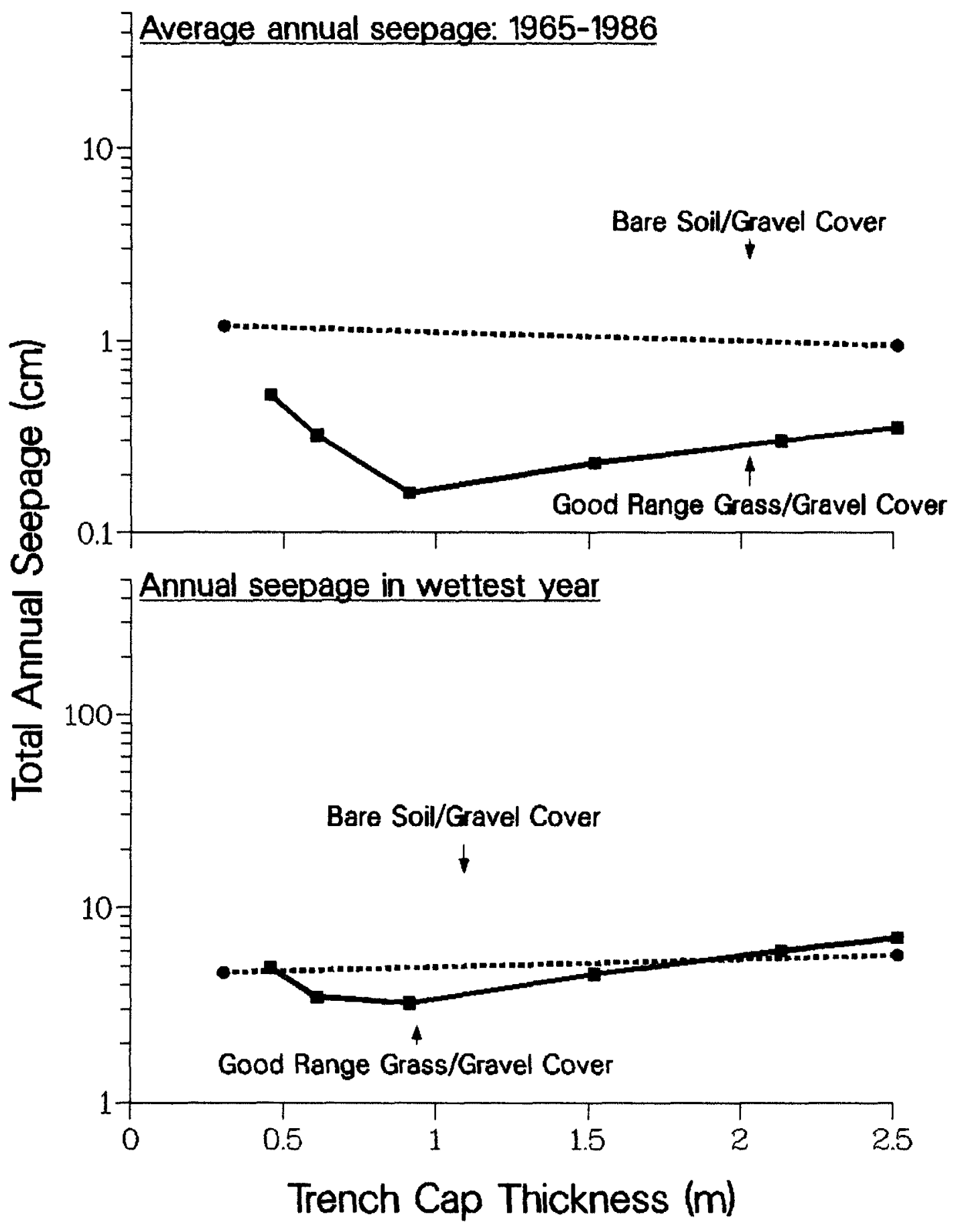

Fig. 17. CREAMS 20-yr simulation using White Rock precıpitation data base for ITP Improved Plot cap design $(\mathrm{CN}=90)$. 
TABLE V. Summary of Selected LAI Data For Areas in the Wester United States. Original Data Interpolated and Extrapolated to a Full Calendar Year (Lane 1984).

\begin{tabular}{|c|c|c|c|c|c|c|c|c|}
\hline $\begin{array}{c}\text { Calendar } \\
\text { Date }\end{array}$ & $\begin{array}{c}\text { Julien } \\
\text { Date }\end{array}$ & $\begin{array}{c}\text { Texas } \\
\text { Meadow } \\
\text { Grass }^{a}\end{array}$ & $\begin{array}{c}\text { Texas } \\
\text { Panhandle } \\
\text { Native } \\
\text { Grass }^{b} \\
\end{array}$ & $\begin{array}{c}\text { Shortgrass } \\
\text { Prarie }^{c}\end{array}$ & $\begin{array}{l}\text { Range } \\
\text { Grass }^{d} \\
\end{array}$ & $\begin{array}{c}\text { Midgrass } \\
\text { Prarie }^{e}\end{array}$ & $\begin{array}{c}\text { Los Alamos } \\
40 \% \text { Cover } \\
\text { Grass and } \\
\text { Shrubs } \\
\end{array}$ & $\begin{array}{c}\text { Rock } \\
\text { Valley, } \\
\text { Nevada, } \\
\text { Desert } \\
\text { Shrubs }^{g}\end{array}$ \\
\hline Jan 1 & 1 & 一 & - & - & - & - & 0.70 & 0.02 \\
\hline Feb 1 & 32 & - & - & - & - & - & 0.70 & 0.02 \\
\hline Mar 1 & 60 & - & - & - & - & - & 0.70 & 0.15 \\
\hline Apr 1 & 91 & - & 0.05 & 0.02 & 0.02 & 0.06 & 0.70 & 0.35 \\
\hline Apr 15 & 105 & 0.70 & 0.06 & 0.06 & 0.03 & 0.35 & 1.00 & 0.33 \\
\hline May 1 & 121 & 1.50 & 0.20 & 0.10 & 0.05 & 0.65 & 1.33 & 0.30 \\
\hline May 15 & 135 & 1.50 & 0.30 & 0.20 & 0.10 & 1.10 & 1.70 & 0.21 \\
\hline June 1 & 152 & 1.50 & 0.47 & 0.33 & 0.20 & 1.49 & 1.70 & 0.10 \\
\hline June 15 & 166 & 1.50 & 0.40 & 0.44 & 0.60 & 1.57 & 1.70 & 0.10 \\
\hline July 1 & 182 & 1.50 & 0.32 & 0.39 & 1.00 & 1.52 & 1.70 & 0.10 \\
\hline July 15 & 196 & 1.50 & 0.24 & 0.32 & 1.00 & 1.32 & 1.70 & 0.10 \\
\hline Aug 1 & 213 & 1.20 & 0.18 & 0.25 & 1.00 & 1.15 & 1.70 & 0.10 \\
\hline Aug 15 & 227 & 0.88 & 0.12 & 0.24 & 0.90 & 1.03 & 1.60 & 0.12 \\
\hline Sept 1 & 244 & 0.45 & 0.05 & 0.05 & 0.80 & 0.82 & 1.50 & 0.15 \\
\hline Scpt 15 & 258 & 0.10 & - & 0.05 & 0.50 & 0.70 & 1.28 & 0.17 \\
\hline Oct 1 & 274 & - & - & 0.05 & 0.20 & 0.69 & 1.08 & 0.20 \\
\hline Nov 1 & 305 & - & - & 0.02 & 0.01 & 0.40 & 0.70 & 0.10 \\
\hline Dec 1 & 335 & - & - & - & - & - & 0.70 & 0.02 \\
\hline Dec 31 & 366 & - & - & - & - & - & 0.70 & 0.02 \\
\hline \multicolumn{9}{|c|}{$\begin{array}{l}{ }^{a} \text { Williams et al. (1980), Figs. II-VIII, p. } 183 . \\
{ }^{b} \text { Becker (1984), Fig. 6, Knight (1973) data adjusted for Texas climate. } \\
{ }^{c} \text { Knight (1973), Fig. 2, average values. } \\
\text { dNyhan and Lane (1982), estimated values. } \\
{ }^{e} \text { Hanson (1973), plots with light grazing at Cottonwood, South Dakota, 1969-1971. } \\
{ }^{f} \text { LAI values estimated for mixed grass and shrubs at Los Alamos, New Mexico. } \\
{ }^{g} \text { Lane et al. (1984), estimated values from leaf biomass, percent cover, and phenology data. }\end{array}$} \\
\hline
\end{tabular}

(Lane 1984) only as first approximations and are not definitive and precise: the user should make on-site measurements of this parameter.

Plant rooting depth and root mass distribution with depth are difficult to measure and are usually obtained by the CREAMS user from soil surveys and from site-specific rooting depth data. Soil surveys usually refer to the distribution of roots in undisturbed soil profiles, unlike what is usually found in the SLB profile. Information as shown in Table VI (Lane 1984) may be used to estimate maximum reported rooting depths.

The winter cover factor in CREAMS reflects the influence of ground cover on hydrologic processes during the winter. The recommendation made previously (Lane 1984) should be followed by the CREAMS uscr: use a winter cover factor of 1.0 for bare soil, otherwise use a value of 0.50 .

One of the first major discoveries made in the use of CREAMS for SLB trench cap designs at Los Alamos was the influence of vegetative cover on decreasing seepage through the SLB trench cap (Nyhan and Lane 1982). Because these early efforts were performed without field-calibrated CREAMS model, we 
Table VI. Maximum Rooting Depth Data to Use as Upper Limit Estimates for Effective Plant Rooting Depth in Water Balance Calculations (Lane 1984; data listed are percent of plants having rooting depths less than the indicated depths.)

\begin{tabular}{lccccc}
\hline Life Form & 36 in. & 72 in. & 108 in. & 144 in. & 180 in. \\
Annual grasses & 75 & 100 & - & - & - \\
Biennial forbs & 65 & 100 & - & - & - \\
Annual forbs & 65 & 88 & 97 & 100 & - \\
Perennial forbs & 42 & 71 & 85 & 93 & 97 \\
Subshrubs & 41 & 85 & 96 & 96 & 96 \\
Perennial grasses & 40 & 79 & 94 & 99 & 99 \\
Evergreen & 33 & 80 & 86 & 86 & 86 \\
Deciduous trees & 7 & 52 & 70 & 78 & 80 \\
Shrubs & 10 & 47 & 60 & 72 & 77 \\
\hline \hline
\end{tabular}

decided to repeat this exercise with our field-calibrated models. The results of these CREAMS simulations are presented in Figs. 10 through 17, where the performance of a trench cap with a bare soil surface with a $70 \%$ cover of gravel is compared with one similar to that found on the ITP Improved Plot (one with a $70 \%$ cover of gravel plus a good cover of range grass).

The results of these comparisons using the OHL precipitation data $(\mathrm{CN}=65)$ cover on the Control Plot design consistantly produces about $12 \mathrm{~cm}$ of annual seepage in the average year and about $21 \mathrm{~cm}$ of annual seepage in the worst case (wettest year), regardless of the thickness of the trench cap. In contrast, the good range grass/gravel cover on this same landfill design produces average annual secpage that ranges from $10.1 \mathrm{~cm}$ to $5.9 \mathrm{~cm}$ as the trench cap thickness increases from 0.31 to $2.5 \mathrm{~m}$ (Fig. 10). In the wettest year, the good range grass/gravel cover produced from $15.7 \mathrm{~cm}$ to $17.6 \mathrm{~cm}$ of annual seepage, whercas the bare soil design produced as much as $28.0 \mathrm{~cm}$ of annual seepage. The major factor causing this observed difference between these two cover designs revolves around the effort of vegetation in enhancing evapotranspiration and, thus, decreasing annual seepage during the plant growing season. Thus, as the trench cap with the good range grass cover becomes thicker, the effective plant rooting depth increases, allowing more and more plant interception of infiltrating precipitation. This effect is even more dramatic on the Improved Plot design because of (1) the enhanced vegetative cover in this cover system compared with the Control Plot design, and (2) the influence of the capillary barrier in retarding water movement out of the plant rooting zone (Fig. 11).

If the results from the good range grass/gravel cover CREAMS simulation (Improved Plot design) wcre used to design a trench cap for long-tcrm repository closure near OHL, we can observe that, with a $0.91-\mathrm{m}$ thickness of the closure trench cap configuration, about $5.2 \mathrm{~cm}$ of annual scepage is predicted to occur in the wettest year (1983) of the 20-ycar period (Fig. 11). However, regardless of whether the CREAMS scepage predictions for the good range grass/gravel cover (Fig. 11) are for the 0.30 -cm cover thickness $(15.6 \mathrm{~cm})$ or the $2.5-\mathrm{m}$-thick trench cap $(8.1 \mathrm{~cm})$, the amounts of annual seepage predicted for the wettest years between 1985 and 1986 are usually about ten-fold larger than the annual seepage occurring on the average year. The reason for this, of course, is that the wettest years are years when snowmelt dominates the scepage production temporal pattern and when plant transpiration does not occur to help reduce seepage production. This is a very important observation because the wettest winters in our study were not even 10-year events, in which $15 \mathrm{~cm}$ of precipitation would be received by the trench cap, let alone a 100-ycar winter, in which even more precipitation would have occurred. Because our CREAMS simulations generally underestimated scepage occurring in the field, the implications for the waste management site operator are that large amounts of percolation could occur in 10-year and 100-year winters, especially when antecendent fall soil moisture levels are large. The conventional trench cap design 
would exhibit the largest amounts of percolation in comparison with a cover containing a capillary barricr. Sufficient field data do not currently exist to predict the efficiency of the capillary barrier in reducing percolation.

\section{B. Precipitation Received at the Site}

Extensive precipitation data are generally available from the National Weather Service in Asheville, North Carolina. However, Los Alamos National Laboratory's daily precipitation data have been collected and compiled by the Environmental Surveillance Group at Los Alamos. The previous section of this report deals with an in-depth evaluatio of precipitation records across the Laboratory.

As was pointed out earlier in this report, both the amount and the seasonal distribution of daily precipitation is an important climatic input term for CREAMS simulations. For the period of record considered in this study, the OHL weather station near the Jemez Mountains (in a Ponderosa Pine vegetative zone) had an average annual precipitation of $49.2 \mathrm{~cm}$, whereas the White Rock station, located further away from the Jemez Mountains (in a Piñon-Juniper woodland) exhibited a similar value of only $34.3 \mathrm{~cm}$.

The effect of only $14.9 \mathrm{~cm}$ of increased annual precipitation was dramatic on seepage production. If only the CREAMS simulations performed for the $0.91-\mathrm{m}$ depth at a $\mathrm{CN}$ value of 65 are considered, the average annual percolation on the Control Plot cover design increased from $5.2 \mathrm{~cm}$ (Fig. 12) to $12.2 \mathrm{~cm}$ (Fig. 10) for the bare soil simulation, as precipitation increased from White Rock to OHL. On the Control Plot design with range grass cover, average annual percolation increased from $1.5 \mathrm{~cm}$ (Fig. 12) to $6.3 \mathrm{~cm}$ (Fig. 10) with this increase in precipitation. Even in the simulation in which vegetation had the largest chance of intercepting percolation, the Improved Plot design with good range grass cover, average annual percolation was only $0.30 \mathrm{~cm}$ (Fig. 13) using the White Rock precipitation as CREAMS input, while a simulated value of $1.6 \mathrm{~cm}$ (Fig. 11) was observed with the OHL precipitation data. However, both trench cap designs exhibited a larger influence of precipitation on predicted percolation when vegetation was present on the landfill cover than for the bare soil conditions (even though generally more percolation occurred under the latter simulations).

\section{Effect of Runoff Curve Number}

Values of $\mathrm{CN}$ may vary from 0.0 (no runoff) to 100 (all precipitation becomes runoff). In general, runoff and $\mathrm{CN}$ values increase (infiltration decreases) proceeding from soils in hydrologic soil groups $\mathrm{A}$ (high infiltration) to D as previously described (Table VII). The very general concept is that $\mathrm{CN}$ values would increase proceeding from a sand to a clay, as the amounts of clay and silt in the soil textural class increased (Table VIII). However, the latter relationship assumes an absence of infiltration restricting or reducing layers, as well as a relatively deep landfill cover profile (1 $\mathrm{m}$ or more in depth). Both SLB designs (Figs. 2 and 3) and most natural systems violate the latter assumption, which makes CREAMS modeling challenging.

However, final $\mathrm{CN}$ estimates can be made by the CREAMS user by considering land use, management and cover complexes, after deciding how the soil is classified (Tables VII and VIII). Lane (1984) suggested $\mathrm{CN}$ values for various hydrologic soil group/vegetation cover complexes, as shown in Table IX. The user should extrapolate from the synthesized data in the table or can conduct on-site field experiments to determine CN values, and should realize that the field data described in Tables VII-IX do not pertain to landfill covers with a partial cover of gravel on the surface as in the ITP experiment (Figs. 2 and 3).

Previous sensitivity analysis of CREAMS on a watershed in Watkinsville, Georgia (Lane and Ferreira 1980), demonstrated that the CN parametcr was very significant parameter in CREAMS, with small changes in $\mathrm{CN}$ resulting in large variations in runoff (effects on percolation were not mentioned). This observation was also made in the current study, but our data show (Figs. 10-17) that the effect on percolation is less dramatic. Taking the $0.91-\mathrm{cm}$-thick Control Plot simulation with the bare soil option as an example, average runoff for the 20-year period of record demonstrated 11 -fold and 2.2-fold increases as a result of increasing precipitation (White Rock versus OHL) at CNs of 65 and 90 , respectively. The average runoff exhibited a 42-fold increase at White Rock and an 8-fold increase at OHL as a result of varying 
Table VII. Summary of Hydrologic Soil Groups and Their Characteristics Used to Define Runoff Curve Numbers (CN) (Lane 1984)

\begin{tabular}{cl} 
Soil & \\
Group & Typical or Unusual Characteristics \\
\hline A & $\begin{array}{l}\text { High infiltration rates even when wetted. } \\
\text { Well-drained to very well-drained gravel, } \\
\text { sand, loamy sands, and sandy loams. Soils } \\
\text { with depths of } 36 \text { in. or more without infil- } \\
\text { tration reducing or restricting layers. }\end{array}$ \\
B & $\begin{array}{l}\text { Moderate infiltration rates. Moderately well- } \\
\text { drained to well-drained soils with moderately } \\
\text { fine to somewhat coarse texture. Usually }\end{array}$ \\
& soils with depths of 20 in. or more. \\
C & $\begin{array}{l}\text { Slow infiltration rates. Moderately fine to } \\
\text { fine texture or infiltration reduction caused } \\
\text { by layering. Usually } 20 \text { in. or less of soil }\end{array}$ \\
& over an infiltration reducing layer. \\
D & Very slow infiltration rates. Clay soils with \\
& swelling potential. Shallow soils over ncarly \\
impervious matcrial (i.e., rock). Usually less \\
than 12 in. of soil over a layer restricting \\
infiltration.
\end{tabular}

Comments

Low runoff potential and very low CNs. Final infiltration rates on the order of 0.30 to $0.45 \mathrm{in} . / \mathrm{h}$ or higher.

Low to moderate runoff potential and CNs. Final infiltration rates on the order of 0.15 to $0.30 \mathrm{in} . / \mathrm{h}$.

Moderate to high runoff potential and CNs. Final infiltration rates on the order of 0.05 to $0.15 \mathrm{in} . / \mathrm{h}$

High runoff potential and CNs. Final infiltration rates on the order of $0.05 \mathrm{in.} / \mathrm{h}$ or less.

the $\mathrm{CN}$ values from 65 to 90 in this same scenario. In contrast, average percolation for the 20 -year record exhibited only a 1.5-fold decrease at both White Rock and OHL as the value of $\mathrm{CN}$ was increased from 65 to 90 (Figs. 10, 12, 14, and 16) in this same modeling scenario.

With these comments in mind, the largest effect of increasing $\mathrm{CN}$ values on average percolation was observed in simulations involving the Improved Plot design. Again, using the 0.91-m-thick profile on the Improved Plot design with the bare-soil cover option as the example, increasing the $\mathrm{CN}$ from 65 to 90 using the White Rock and OHL precipitation bases resulted in decreases of 4.0 times and 3.1 times in average percolation, respectively (Figs. 11, 13, 15, and 17). Most of the other observed changes because of varying $\mathrm{CN}$ in this range resulted in less than two-fold comparable changes in average percolation, with the influence of increased precipitation having a more pronounced effect on percolation than precipitation in the Control Plot design.

\section{USEFULNESS OF SIMULATIONS FOR WASTE MANAGEMENT PRACTICES AT LOS ALAMOS AND RECOMMENDATIONS FOR FUTURE STUDIES}

The usefulness of this hydrologic modeling exercise is that it demonstrates that SLB design characteristics, such as trench cap thickness, do not have to be arbitrarily chosen. Now that field-calibrated hydrologic models exist that can describe water balance relationships for the improved and control SLB design configuration at Los Alamos, CREAMS can be used as a tool to improve the design of SLB, using engineering design criteria such as portrayed in Figs. 10-17. These design criteria can be used to optimize SLB water balance relationships for long-term closure covers for landfills at the Laboratory. 
TABLE VIII. Approximate Composition of 12 Soil Textural Classes and Their Relationships with Hydrologic Soil Groups Without Infiltration Restricting Layers (Lane 1984)

\begin{tabular}{lcccc}
\hline $\begin{array}{l}\text { Soil Texture } \\
\text { Class }\end{array}$ & Clay (\%) & Silt (\%) & Sand (\%) & $\begin{array}{c}\text { Hydrologic Soil } \\
\text { Group Association }\end{array}$ \\
\hline Sand & 3 & 7 & 90 & A \\
Loamy sand & 5 & 15 & 80 & A \\
Sandy loam & 10 & 20 & 70 & A to B \\
Loam & 20 & 40 & 40 & A to C \\
Silt loam & 15 & 65 & 20 & A to D \\
Silt & 5 & 87 & 8 & B to C \\
Sandy clay loam & 30 & 10 & 60 & A to D \\
Clay loam & 35 & 35 & 30 & C to D \\
Silty clay loam & 35 & 55 & 10 & D \\
Sandy clay & 45 & 5 & 50 & B to D \\
Silty clay & 45 & 50 & 5 & D \\
Clay & 65 & 20 & 15 & D \\
\hline
\end{tabular}

More specifically, the best recommendation that can be made to the unltimate user of this report, the burual site operator, to obtain the help of field-orientetd soil scientist and a hdyrologist to derive design recommendations for a specific landfill with the Laboratory. These scientists can then use the general modeling data presented in Figs. 10 through 17 to bound the magnitude of the extreme solutions to the optimal SLB design configuration, using site-specific information. In this process, the information presented in the last two sections of this report will be very helpful.

For example, if the landfill under consideration is located in an area within the Laboratory with either pondersa pine or piñon-juniper vegetation, the OHL or White Rock weather records, respectively, whould be used to evaluate SLB designs. On the other hand, the emperature and solar radiation data collected at the OHL weather station(in a ponderosa pine vegetation zone) can be safely used to represent every landfill within the Laboratory in the CREAMS model.

Once the soil scientist has characterized the soils and crushed tuff backfill materials to be used at a specific landfill, the hydrologist can derive a $\mathrm{CN}$ value for the hydrologic modeling of the site. Because the specific value that the hydrologist will ultimately derive will probably be between 65 and 90 (see Table IX), the CREAMS simulation results presented in Figs. 10 through 17 for both of these extreme cases (65 and 90) will probably bound the CREAMS modeling results for the hydrologist's specific CN value.

An on-going field study at Waste Disposal Area B is currently studying runoff/infiltration characteristics of trench cap cover treatments consisting of shrubs, grasses, and shrub and grass covers with a partial gravel cover. One future area of highly recommended modeling activities would be to investigate the influence of reducing $\mathrm{C}$ in CREAMS simulation results at Area $\mathrm{B}$. The ITP modeling activities performed in previous studies indicated that $C$ values should be decreased dramatically over those suggested to be used (Lane 1984) when a gravel cover was involved. Further field validation of this effect would greatly enhance the accuracy of the CREAMS predictions of seasonal scepage in SLB designs, since a partial gravel cover will certainly be used in the Area $P$ landfill designs to reduce erosion of the closure cover. The near-surface field studies performed at Waste Disposal Area B will also greatly enhance our ability to predict soil loss rates for different cover treatments using the erosion component of CREAMS.

Another recommendation can be made as a result of the overall modeling efforts in this study. Appreciable annual seepage is predicted to occur as precipitation increases, either between locations or within one location over a long time period. Using the CREAMS simulation on a 0.9 -m-thick improved trench 
TABLE IX. Runoff CN for Various Hydrologic Soil Group/Cover Complexes, Antecedent Condition II Percent Cover Designations are Approximate; Lane 1984)

\begin{tabular}{|c|c|c|c|c|}
\hline \multirow[b]{2}{*}{ Cover Type and Conditions } & \multicolumn{4}{|c|}{ Runoff by Soil Groups } \\
\hline & A & B & $\mathrm{C}$ & $\mathrm{D}$ \\
\hline $\begin{array}{l}\text { Hard, compacted surfaces } \\
\text { such as dirt roads, etc. }\end{array}$ & 74 & 84 & 90 & 92 \\
\hline Unimproved bare soil & 72 & 82 & 87 & 90 \\
\hline \multicolumn{5}{|l|}{ Desert brush } \\
\hline$<10 \%$ cover & * & 84 & 88 & 93 \\
\hline $20 \%$ cover & * & 83 & 87 & 92 \\
\hline $40 \%$ cover & * & 82 & 86 & 90 \\
\hline \multicolumn{5}{|l|}{ Pasture or range } \\
\hline poor & 68 & 79 & 86 & 89 \\
\hline fair & 49 & 69 & 79 & 84 \\
\hline good & 39 & 61 & 74 & 80 \\
\hline \multicolumn{5}{|l|}{$\begin{array}{l}\text { Herbaceous plants, brush, } \\
\text { and grass }\end{array}$} \\
\hline $20 \%$ cover & * & 79 & 86 & 92 \\
\hline $40 \%$ cover & $*$ & 74 & 82 & 90 \\
\hline \multicolumn{5}{|l|}{ Pinon/juniper/grass } \\
\hline $40 \%$ cover & * & 65 & 75 & 88 \\
\hline $60 \%$ cover & * & 57 & 70 & 86 \\
\hline $80 \%$ cover & * & 48 & 62 & 83 \\
\hline \multicolumn{5}{|l|}{ Ponderosa pine } \\
\hline $40 \%$ cover & * & 61 & 75 & 80 \\
\hline $60 \%$ cover & * & 55 & 70 & 77 \\
\hline $80 \%$ cover & * & 49 & 65 & 73 \\
\hline
\end{tabular}

cap design as an example (with $\mathrm{CN}=65$, good range grass/gravel cover; Figs. 11 and 13), average annual scepage increased from 0.12 in. to 0.63 in. (a 5.3-fold increase) as average annual precipitation increased from 13.5 in. at White Rock to 19.4 in. at the OHL station. Using this same modcling simulation at the OHL station, as precipitation from 1965 to 1986 increased from the average annual precipitation of 19.4 in. to the maximum annual precipitation in 1984 of $25.5 \mathrm{in}$., annual seepage production increased from 0.63 to 2.1 in. (a 2.3 -fold increase), respectively. The importance of the latter observation can bc better understood by realizing that the maximum annual precipitation in 1984 was only about a 10-year annual event (Table IV). A 100-year precipitation event in Los Alamos (Table IV) would result in 32.9 in., which would result in much more than 2.1 in. of annual secpage.

Especially in view of the potential impact of the 100-year annual seepage event, capillary barriers should be used in the long-term closure designs of all SLB facilities. Because the Improved Plots contained capillary barriers that dramatically reduce annual seepage, this data base should be further cxpanded by 
collection of field data at other landfills in the future. The field data and the modeling expertise is unique to Los Alamos and does not exist anywhere else in the U.S.

A possible alternative or enhancement to the use of capillary barriers might be to dramatically reduce winter seepage using conifers. Using an evergreen cover on the trench cap, in addition to a good cover of range grass, could greatly enhance evapotranspiration in the winter and early spring, thus reducing seepage in the wettest years (worst case) described in this study. This would probably make a good waste management decision, but would necessitate further studies of capillary/biointrusion barriers in prohibiting conifer roots from penetrating waste materials beneath the trench cap.

Finally, I would recommend additional future field research and concurrent hydrologic modeling in three other areas involved in the water balance equation. First, transpiration studies of various grass, shrub, and tree species need to be performed in the field at scale larger than our 3- by 10-m ITP. The ultimate precision of a model like CREAMS to predict evapotranspiration will depend on our ability to accurately describe both the seasonal transpiration and evaporation processes involved. The second area that needs further research involves further field investigations into seepage production in SLB configurations. Without seepage field data, both evapotranspiration and runoff parameter estimates need to be directly measured, which may not be currently possible with the technology at hand. Finally, a reliable technique needs to be developed and evaluated for determining $\mathrm{K}$ for the field soils that agrees with the model estimates of K. A good field estimate of $\mathrm{K}$ that represents a large field area would take a lot of guesswork out of CREAMS parameter estimation, resulting in greatly enhanced accuracy in model predictions.

\section{REFERENCES}

1. Abeele, W. V., "Geotechnical Aspects of Hackroy Sandy Loam and Crushed Tuff," Los Alamos National Laboratory report LA-9916-MS (1984).

2. Day, S. R., and D. E. Danicl, "Hydraulic Conductivity of Two Prototype Clay Liners," in "Land Disposal of Hazardous Waste, Proceedings of the Eleventh Annual EPA Research Symposium," EPA Report EPA/600/9-85/013, p. 265 (April 1985).

3. DePoorter, G. L., "The Los Alamos Experimental Enginecred Waste Burial Facility: Design Considerations and Preliminary Experimental Plan," in Waste Management '81, R. G. Post and M. E. Wacks, Eds., (University of Arizona, Tucson, Arizona, 1981), pp. 667-686.

4. Hakonson, T. E., L. J. Lane, J. G. Steger, and G. L. DePoorter, "Some Interactive Factors Affecting Trench Cover Integrity of Low-level Waste Sites," NRC report NUREG/CP-0028, Vol. II (1982).

5. Jackson, R. D., S. B. Idso, and R. J. Reginato, "Calculation of Evaporation Rates During the Transition from Energy-Limiting to Soil-Limiting Phases Using the Albedo Data," Water Resources Research 12, 23-26 (1976).

6. Knisel, W. G., Jr., Ed., "CREAMS: A Field-scale Model for Chemicals, Runoff, and Erosion from Agricultural Management Systems," USDA-Conservation Research Report No. 26 (1980).

7. Lane, L. J., "Surface Water Management: A User's Guide to Calculate a Water Balance Using the CREAMS Model," Los Alamos National Laboratory report LA-10177-M (1984).

8. Lane, L. J., and V. A. Ferreria, "Sensitivity Analysis," in "CREAMS: A Field-Scale Model for Chemicals, Runoff, and Erosion from Agricultural Management Systems," U.S. Department of Agriculture, Conservation Research report No. 26 (1980), pp. 113-158.

9. Lane, L. J., E. M. Romney, and T. E. Hakonson, "Water Balance Calculations and Net Production of Perennial Vegetation in the Northern Mojave Desert," Journal of Range Management 37 12-18 (1984). 
10. Nyhan, J. W., "Development of Technology for the Long-Term Stabilization and Closure of Shallow Land Burial Sites in Semiarid Environments," Los Alamos National Laboratory report LA-11283-MS (1989).

11. Nyhan, J. W., and F. J. Barnes, "Development of a Prototype Plan for the Effective Closure of a Waste Disposal Site in Los Alamos, New Mexico," Los Alamos National Laboratory report LA-11282-MS (1989).

12. Nyhan, J. W., R. Beckman, and B. Bowen, "An Analysis of Precipitation Occurrences in Los Alamos, New Mexico for Long-Term Predictions of Waste Repository Behavior," Los Alamos National Laboratory report LA-11459-MS (1989a).

13. Nyhan, J. W., G. L. DePoorter, B. J. Drennon, J. R. Simanton, and G. R. Foster, "Erosion of Earth Covers Used in Shallow Land Burial at Los Alamos, New Mexico," Journal of Environmental Quality 13:361-366 (1984).

14. Nyhan, J., B. Drennon, and T. Hakonson, "Field Evaluation of Two Shallow Land Burial Trench Cap Designs for Long-Term Stabilization and Closure of Waste Repositories at Los Alamos, New Mexico," Los Alamos National Laboratory report LA-11281-MS (1989b).

15. Nyhan, J. W., B. J. Drennon, J. C. Rodgers, and W. V. Abeele, "Spatial Resolution of Soil Water Content by Three Neutron Moisture Gauges," Los Alamos National Laboratory document LA-UR-832863 (1983).

16. Nyhan, J. W., T. E. Hakonson, and E. A. Lopez, "Corrective Measures Technology for Shallow Land Burial at Arid Sites: Field Studies of Biointrusion Barriers and Erosion Control," Los Alamos National Laboratory report LA-10573-MS (1986).

17. Nyhan, J. W. and L. J. Lane, "Use of a State-of-the-Art Model in Generic Designs of Shallow Land Repositories for Low-Level Wastes," in Waste Management '82, R. G. Post and M. E. Wacks, Eds. (University of Arizona, Tucson, Arizona 1982), Vol. 2, pp. 235-244.

18. Nyhan, J. W., and L. J. Lane, "Erosion Control Technology: A User's Guide to the Use of the Universal Soil Loss Equation at Waste Burial Facilities," Los Alamos National Laboratory report LA-10262-MS (April 1986).

19. Pathak, C. S., F. R. Crow, and R. L. Bengston, "Comparative Performance of Two Runoff Models on Grassland Watersheds," Transactions ASAE 27:397-406 (1984).

20. Ritchie, J. T., "Model for Predicting Evaporation from a Row Crop with Incomplete Cover," Water Resources Research 8:1204-1213 (1972).

21. Schroeder, P. R., J. M. Morgan, T. M. Walski, and A. C. Gibson, "The Hydrologic Evaluation of Landfill Performance (HELP) Model," EPA report Vols. I and II, EPA/530-SW-84-010, U.S. Environmental Protection Agency, Office of Solid Waste and Emergency Response (1984).

22. U.S. Nuclear Regulatory Commission, Rules and Regulations, Title 10, Chapter 1, Code of Federal Regulations, Part '61, "Licensing Requirements for Land Disposal of Radioactive Waste," (10 CFR 61), December 30, 1982.

23. U.S. Environmental Protection Agency, "Interim Status Standards for Owners and Operators of Hazardous Waste Facilities," Title 40, Code of Federal Regulations, Part 265 (40 CFR 265) in Federal Register, Vol. 45, May 19, 1980. 
24. U.S. Environmental Protection Agency, "Environmental Standards for the Management and Disposal of Spent Fuel, High-Level and Transuranic Radioactive Waste," (50 CFR 191) in Federal Register, Vol. 50, No. 182, September 19, 1985. 